\title{
Rational Drug Design of Targeted and Enzyme Cleavable Vitamin E Analogs as Neoadjuvant to Chemotherapy: In Vitro and In Vivo Evaluation on Reduction of Cardiotoxicity of Doxorubicin.
}

Raghu Pandurangi $1^{*}$, Orsolya $\mathrm{Cseh}^{2}, \mathrm{H}$. Artee Luchman², Siguang $\mathrm{Xu}^{3}$, Cynthia $\mathrm{Ma}^{3}$, Sanjeewa

N. Senadheera ${ }^{4}$ and Laird Forrest ${ }^{4}$

1. President, CSO, Sci-Engi-Medco Solutions Inc (SEMCO), 573, Lexington Landing PI, St

Charles, 2. MO 63303, 2. HRIC 2A25, 3330 Hospital Drive NW, Calgary, AB, T2N 4N, Canada

3. Siteman Cancer Center, Washington University School of Medicine, St. Louis, Missouri, USA.

4. Department of Pharmaceutical Chemistry, School of Pharmacy, University of Kansas,

Lawrence, KS 66047, USA

${ }^{*}$ Author for correspondence 


\section{Abstract \\ Traditional drug design focus on specific target (s) expressed by cancer cells.} However, cancer cells outsmart the interventions by activating survival pathways and/or downregulating cell death pathways. As the research in molecular biology of cancer grows exponentially, new methods of drug designs are needed to target multiple pathways/targets which are involved in survival of cancer cells. Vitamin E analogues including a-tocopheryl succinate $(\alpha-$ TOS) is a well-known anti-tumoregenic agent which is well studied both in vitro and in vivo tumor models. However, lack of targeting cancer cells and unexpected toxicity along with the poor water solubility of $\alpha$-TOS compelled a rational drug design using both targeting and cleavable technologies incorporated in the new drug design. A plethora of Vitamin E derivatives (AMP-001, 002 and 003) were synthesized, characterized and studied for the improved efficacy and lowered toxicity in various cancer cells in vitro. Preliminary studies revealed AAAPT leading candidates reduced the invasive potential of brain tumor stem cells, synergized with different drugs and different treatments. AAAPT leading drug AMP-001 enhanced the therapeutic index of front-line drug Doxorubicin in triple negative breast cancer (TNBC) tumor rat model preserving the ventricular function when used as a neoadjuvant to Doxorubicin. These results may pave the way for reducing the cardiotoxicity of chemotherapy in clinical settings. 


\section{Introduction}

Conventional drug designs are based on the identification of specific biological targets involved in the progression of disease, varied target expression in patients, binding of the potential drug to target and modification of the target post binding of the drug ${ }^{1}$. Recent investigations on the molecular biology of cancer open a new type of targets namely, pathways involved in the tumorigenesis $^{2}$. For example, cancer cells enhance the survival pathways and/or enzymes (e.g. NF-kB pathway, PARP) and inhibit or downregulate the cell death pathways (e.g. CD95, ASK1) to desensitize themselves to intervention, irrespective of the nature of intervention ${ }^{3}$. Unfortunately, the same pathways are involved in normal cell growth, despite the levels of enzymes or activating/inhibiting potential of pathways may vary to a great extent. The concept of drug targeting using tumor specific biomarkers is not new for oncology drugs. However, targeting the dysregulated pathways involved in the desensitization process is still relatively new.

$\alpha$-tocopheryl derivatives are class of compounds which showed interesting biological activities for cancer treatment ${ }^{4}$. Particularly, $\alpha$-tocopheryl succinate ( $\alpha$-TOS) has shown tremendous antitumorigenic potential both in vitro and in vivo tumor models ${ }^{5}$. However, on extending the promising work of $\alpha$-TOS to immunocompetent tumor model which could be translational to clinical product lack the required safety profile for commercialization ${ }^{6}$. For example, studies in an immunocompetent mouse in vivo model showed that $\alpha$-TOS was not only ineffective at the published doses but also resulted in severe side effects due to lack of targeting ${ }^{6}$. $\alpha$-TOS also faced problems with water solubility, bioavailability and formulation issues demanding encapsulation of the drug into liposomes ${ }^{7}$. The lack of proof of targeting, particularly in vivo appears to be responsible for the lack of clinical product so far, for $\alpha$-TOS. Here, we report various derivatives of $\alpha$-TOS (antioxidant) incorporating targeting vector, cleavable linker and pegylation to improve the pharmacokinetic parameters required for clinical applications. Our studies show 
an immense improvement in targeting cancer cells by AAAPT drugs, particularly cancer stem cells (CSCs) and cancer resistant cells (CRCs) which are presumably responsible for the treatment failure and recurrence of cancer $^{8}$. The leading drug is also designed with two linkers cleavable by low $\mathrm{pH}^{9}$ and Cathepsin $\mathrm{B}^{10}$ which is overexpressed in several cancers.

Triple negative breast cancer (TNBC) is an aggressive disease, which disproportionately accounts for nearly half of all breast cancer-related deaths, compared to 15$20 \%$ of breast cancer patients ${ }^{11}$. Occurring primarily in women younger than 50 years of age, TNBC prevalence is highest in patients of African American and Hispanic descent ${ }^{12}$. The mortality rate for TNBC patients is $40 \%$ within 5 years of diagnosis ${ }^{13}$. Patient survival after cancer recurrence, within 3-5 years of diagnosis rarely extends beyond 12 months ${ }^{14}$. Without effective treatment strategies, roughly 20,000 of TNBC patients die yearly in the U.S. alone, making the development of potent TNBC therapies an urgent medical need ${ }^{15}$.

TNBC is typically classified as grade 3 are metastatic in nature in $66 \%$ of patients, with large tumors and metastatic spread to visceral organs, lung or brain already present ${ }^{16}$. TNBC cells lack the expression of biomarkers, such as estrogen receptor (ER), progesterone receptor (PR) or human epidermal growth factor receptor HER-2, which are used in the design of potent targeted therapies. Hence, current targeted therapy may not work efficiently for TNBC patients ${ }^{17}$. Cellular and molecular heterogeneity is another important hallmark of TNBC tumors, further hindering the design of targeted therapies ${ }^{18}$.

Together, these factors warrant current use of cytotoxic front-line chemotherapeutics as primary neoadjuvant, adjuvant and metastatic treatment modality for $\mathrm{TNBC}^{19}$. Chemotherapy, particularly anthracyclines are still the first line of treatments for cancer, despite high off-target toxicity, including well reported cardiotoxicity, induction of stemness to expand cancer stem cells (CSCs), eliminate bone marrow cells and may have to be stopped due to lymphedema ${ }^{20}$. This is a serious clinical problem which results in an increase in recurrence rate (13\% for kidney cancer, 
$36 \%$ for breast and almost $100 \%$ for brain cancer) and make tumors refractory to future treatments ${ }^{21}$. The risk of anthracycline related cardiomyopathy increases with a higher cumulative anthracycline dose $\mathrm{e}^{22}$. About $3 \%$ of the dose persist even after the completion of therapy leading to heart failure and death for a dose $400 \mathrm{mg} / \mathrm{m}^{2}, 7 \%$ for a dose of $550 \mathrm{mg} / \mathrm{m}^{2}$, and $18 \%$ for a dose of $700 \mathrm{mg} / \mathrm{m}^{2}$. Chronic anthracycline related cardiotoxicity (ARC) and subsequent adverse sequelae was reported to be around $50 \%$ of all the cases ${ }^{23}$. Reversal of cardiotoxicity is possible with a combination of oncology and cardiology drugs provided an early diagnosis is made (e.g. poly (ADP-ribose) polymerase (PARP) inhibitors ${ }^{24}, \mathrm{NF}-\mathrm{kB}$ inhibitors ${ }^{25}$ and some natural antioxidants ${ }^{26}$ ). Hence, predicting $\mathrm{ARC}$ and reversal of cardiotoxicity using a combined formulation of drugs in vivo is a top priority in the management of cancer patients which can lead to quality of life, particularly for triple negative breast cancer (TNBC) patients who have no option, but to rely on chemotherapy, despite high off-target toxicity ${ }^{27}$.

Here we want to report the synthesis and biological evaluation of leading AAAPT dugs in vitro in various types of cancer cells and to show that these derivatives are synergistic with the current treatments (e.g. doxorubicin, paclitaxel), particularly for TNBC treatment. AMP-001 showed a significant potential to reduce the invasive potential of brain tumor stem cells (BTSCs). We have also investigated the anti-tumorigenic potential of AMP-001 in vivo using rat TNBC model where the synergistic potential of AMP-001 with doxorubicin resulted in lowering the Doxorubicin dose by $50 \%$ yet inducing significant tumor regression and preserving ventricular function compared to Doxorubicin alone.

\section{Material and Methods}

Synthesis of the four leading drugs will be described. All precursor chemicals were bought from Sigma and used as such using MSDS data. 


\section{Scheme 1}

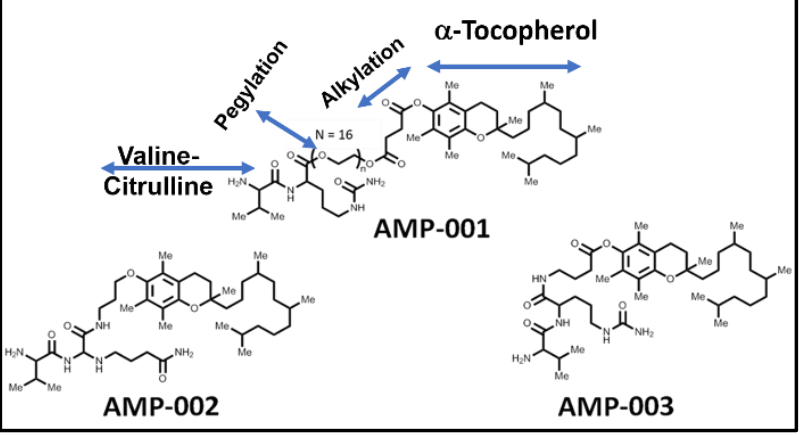

Synthesis of AMP-001. AMP-002 and AMP-003:

AAAPT drugs have three parts: a) $\alpha$-tocopherol part, alkylation part and dipeptide valine-citrulline (Scheme 1). The precursor of all AMP class of compounds is $\alpha$-tocopherol which was modified by an alkyl chain either with ether link (AMP-002) or

with ester link (AMP-003). AMP-001 was pegylated after alkylating $\mathrm{OH}$ group of tocopherol before conjugating with valine-citrulline di peptide linker.

\section{A) Alkylation of $\alpha$-tocopherol with Ether link to get Tocopheryl oxy propyl amine (TOPA).}

Scheme 2

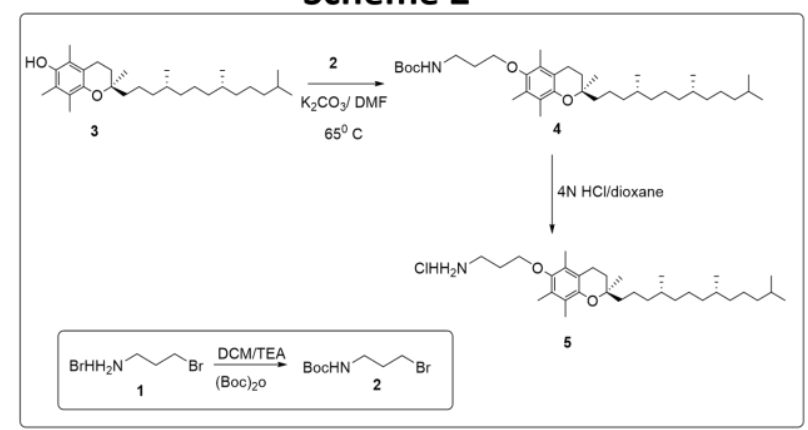

Step 1: Tert-butyl

bromopropyl)carbamate 2: To a stirred suspension of compound $1(2.5 \mathrm{~g}, 11.46$ mmol) in Dry DCM (25 $\mathrm{mL})$ was added TEA $(5.6 \mathrm{~mL}, 40.11 \mathrm{mmol})$ at $0^{0} \mathrm{C}$ under inert

atmosphere. To this Boc anhydride $(2.5 \mathrm{~mL}, 11.46 \mathrm{mmol})$ was added in drop wise over the period of $15 \mathrm{~min}$. The reaction mixture was stirred at RT for $6 \mathrm{~h}$. After completion of the reaction (by TLC), the reaction mixture was diluted with ice-cold water $(75 \mathrm{~mL})$ and extracted with DCM $(3 \mathrm{x}$ $75 \mathrm{~mL})$. The combined organic extracts were washed with water $(75 \mathrm{~mL})$, brine $(50 \mathrm{~mL})$, dried over anhydrous $\mathrm{Na}_{2} \mathrm{SO}_{4}$ and concentrated under reduced pressure. The obtained crude material was purified by silica gel column chromatography (SiO2, 60-120 mesh) (eluent: 10\% EtOAc/Hexane) to afford compound 2 (2.6 g, 10.92 mmol, 95\%) as sticky syrup. ${ }^{\mathbf{1}} \mathbf{H}$ NMR (400 MHz, $\mathbf{C D C l}_{3}$ ): $\delta 4.92(\mathrm{bs}, 1 \mathrm{H}), 3.52(\mathrm{t}, J=7.2 \mathrm{~Hz}, 1 \mathrm{H}), 3.27(\mathrm{t}, J=7.5 \mathrm{~Hz}, 2 \mathrm{H}), 2.19(\mathrm{q}, J=8.2$ $\mathrm{Hz}, 2 \mathrm{H}), 1.91(\mathrm{~s}, 9 \mathrm{H}) . \mathbf{M S}(\mathrm{ESI}): \mathrm{m} / \mathrm{z} 239\left[\mathrm{M}^{+}+1\right]$. 


\section{Step II . tert-butyl(3-(((R)-2,5,7,8-tetramethyl-2-((4R,8R)-4,8,12-trimethyltridecyl)chroman-6- yl)oxy)propyl)carbamate 4:}

To a stirred solution of Tocopherol $3(2.5 \mathrm{~g}, 5.81 \mathrm{mmol})$ in dry DMF $(15 \mathrm{~mL})$ was added compound 2 (2.49 $\mathrm{g}, 10.46 \mathrm{mmol})$ followed by $\mathrm{K}_{2} \mathrm{CO}_{3}(2.3 \mathrm{~g}, 17.43 \mathrm{mmol})$ at $\mathrm{RT}$ under inert atmosphere. The resulting reaction mixture was gradually heated up to $65^{\circ} \mathrm{C}$ and stirred for 16 $\mathrm{h}$; progress of the reaction was monitored by TLC. The reaction mixture was diluted with ice-cold water $(50 \mathrm{~mL})$ and extracted with EtOAc $(3 \times 75 \mathrm{~mL})$. The combined organic extracts were washed with water $(75 \mathrm{~mL})$, brine $(50 \mathrm{~mL})$, dried over anhydrous $\mathrm{Na}_{2} \mathrm{SO}_{4}$ and concentrated under reduced pressure. The crude material was purified by silica gel column chromatography (SiO2, 60-120 mesh) (eluent: 15\% EtOAc/Hexane) to afford compound 4 (2.4 g, $4.08 \mathrm{mmol}, 62 \%)$ as off white solid.

${ }^{1}$ H NMR (5 00 MHz, CDCl3): $\left.\delta 3.75(t, J=8.2 \mathrm{~Hz}, 2 \mathrm{H})\right), 3.43(\mathrm{t}, J=8.2 \mathrm{~Hz}, 2 \mathrm{H}), 2.67(\mathrm{t}, J=7.2$ $\mathrm{Hz}, 3 \mathrm{H}), 2.35(\mathrm{t}, \mathrm{J}=7.2 \mathrm{~Hz}, 2 \mathrm{H}), 2.19-2.00(\mathrm{~m}, 9 \mathrm{H}), 1.79-1.67(\mathrm{~m}, 2 \mathrm{H}), 1.60-1.48(\mathrm{~m}, 3 \mathrm{H}), 1.43-$ $1.11(\mathrm{~m}, 23 \mathrm{H}), 1.49(\mathrm{~s}, 9 \mathrm{H}), 0.92-0.82(\mathrm{~m}, 12 \mathrm{H}) . \mathbf{M S}$ (ESI): $m / z 588[\mathrm{M}+1]^{+}$

\section{Step 3: 3-(((R)-2,5,7,8-tetramethyl-2-((4R,8R)-4,8,12-trimethyltridecyl)chroman-6- yl)oxy)propan-1-amine hydrochloride 5:}

To a stirred solution of compound-4 $(2.3 \mathrm{~g}, 3.91 \mathrm{mmol})$ in dry 1,4-dioxane $(5 \mathrm{~mL})$ was added 4 $\mathrm{N}$ 1,4-dioxane solution in $\mathrm{HCl}(2.3 \mathrm{~mL})$ at $0^{\circ} \mathrm{C}$ under inert atmosphere. The resulting reaction mixture was stirred at RT for $9 \mathrm{~h}$. After completion of the reaction (by TLC), The resulting mixture was concentrated under reduced pressure to get the sticky syrup, after washing with Ether (HPLC, $2 \times 20 \mathrm{~mL}$ ) to afford fine brown solid as compound 5 (1.2 g, 2.45mmol, 62\%)

${ }^{1} \mathrm{H}$ NMR ( Varian,400 MHz, CDCl3): $\delta 8.35$ (bs, 3H), $\left.\delta 3.35(\tau, J=8.2 \mathrm{~Hz}, 2 \mathrm{H})\right), 3.43(\mathrm{t}, J=8.2 \mathrm{~Hz}$, 2H), $2.52(\mathrm{t}, J=7.2 \mathrm{~Hz}, 3 \mathrm{H}), 2.35(\mathrm{t}, J=7.2 \mathrm{~Hz}, 2 \mathrm{H}), 2.19-2.00(\mathrm{~m}, 9 \mathrm{H}), 1.79-1.67(\mathrm{~m}, 2 \mathrm{H}), 1.60-$ 
$1.48(\mathrm{~m}, 3 \mathrm{H}), 1.41-1.10(\mathrm{~m}, 23 \mathrm{H}), 0.90-0.80(\mathrm{~m}, 12 \mathrm{H})$. MS (ESI): $m / z 488[\mathrm{M}+1]^{+}$, HPLC: $92.99 \%$.

B) Alkylation of $\alpha$-tocopherol with ester link to get Tocopheryl propyl ester amine (TPEA.

\section{Step 1: 4-((tert-butoxycarbonyl) amino)butanoic acid 2}

To a stirred suspension of 4-aminobutanoic acid 1 (1.5 g, $14.56 \mathrm{mmol})$ in 1, 4-dioxane (15 $\mathrm{mL}$ ) was added $1 \mathrm{~N} \mathrm{NaOH}$ solution $(1.5 \mathrm{~mL})$ at $0^{\circ} \mathrm{C}$ under inert atmosphere. To this Boc anhydride

Scheme 3

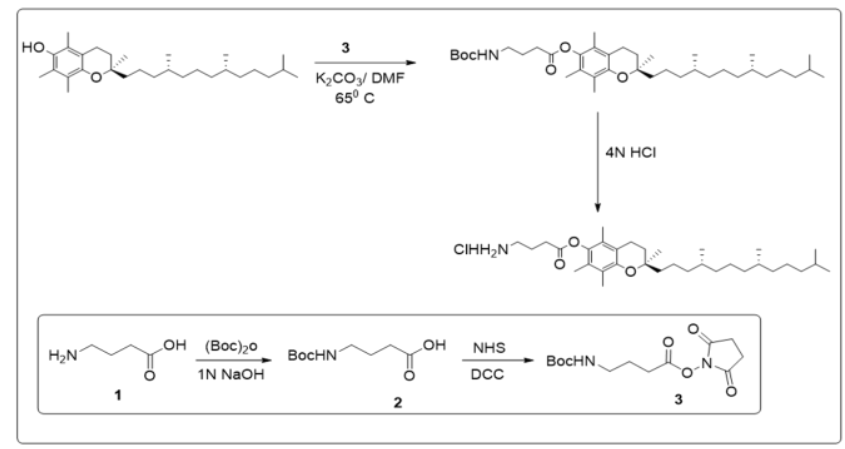

(3.1 $\mathrm{mL}, 14.56 \mathrm{mmol}$ ) was added in drop wise over the period of $10 \mathrm{~min}$. The reaction mixture was stirred at RT for $4 \mathrm{~h}$. After completion of the reaction (by TLC), the reaction mixture $\mathrm{pH}$ was adjusted to 2 , by the addition of aqueous $\mathrm{K}_{2} \mathrm{HSO}_{4}$ solution (10

$\mathrm{mL})$, quenched with ice-cold water $(50 \mathrm{~mL})$ and extracted with EtOAc $(2 \times 75 \mathrm{~mL})$. The combined organic extracts were washed with water $(50 \mathrm{~mL})$, brine $(50 \mathrm{~mL})$. The organic layer was dried over anhydrous $\mathrm{Na}_{2} \mathrm{SO}_{4}$ and concentrated under reduced pressure to afford compound 2 ( $2.9 \mathrm{~g}$, $14.28 \mathrm{mmol}, 98 \%$ ) as white sold. ${ }^{1} \mathrm{H}$ NMR (500 MHz, $\left.\mathbf{C D C l}_{3}\right): \delta 4.65$ (bs, $\left.1 \mathrm{H}\right), 3.25$ (d, J = 8.2 Hz, 1H), 2.44-2.38 (m, 2H), 1.86-1.78 (m, 2H ), 1.41(s, 9H). MS (ESI): m/z $204\left[\mathrm{M}^{+}+1\right]$

\section{Step 2: 2,5-dioxopyrrolidin-1-yl 4-((tert-butoxycarbonyl)amino)butanoate 3.}

DCC $(2.84 \mathrm{~g}, 13.79 \mathrm{mmol})$ was added to a solution of compound $2(2.8 \mathrm{~g}, 13.79 \mathrm{mmol})$ and $\mathrm{N}$ hydroxysuccinamide $(1.58 \mathrm{~g}, 13.79 \mathrm{mmol})$ in 1,4-dioxane $(28 \mathrm{~mL})$, and the mixture was stirred at RT for $3 \mathrm{~h}$, under inert atmosphere. After completion of the reaction (by TLC), diluted with 1, 4dioxane $(30 \mathrm{~mL})$ solution, filtered through a pad of celite, obtain filtrate was concentrated under reduced pressure to get the off white solid as compound 3 ( 3.6 g crude), which was directly used next step with out further purification. 
${ }^{1}$ H NMR (500 MHz, DMSO- $\left.d_{6}\right): \delta 3.10(q, J=8.2 \mathrm{~Hz}, 1 \mathrm{H} \mathrm{2H}), 2.69(\mathrm{t}, J=8.2 \mathrm{~Hz}, 2 \mathrm{H}), 1.70-1.68$ $(\mathrm{m}, 2 \mathrm{H}), 1.39(\mathrm{~s}, 9 \mathrm{H}) . \mathbf{M S}(\mathbf{E S I}): \mathrm{m} / \mathrm{z} 304\left[\mathrm{M}^{+}+1\right]$

Step 3: (2S)-2,5,7,8-tetramethyl-2-(4,8,12-trimethyltridecyl)chroman-6-yl4-((tertbutoxycarbonyl)amino)butanoate 5 .

To a stirred solution of compound $4(2.5 \mathrm{~g}, 5.81 \mathrm{mmol})$ in dry DMF (15 mL) was added compound 3 (3.1 g, Crude) followed by $\mathrm{K}_{2} \mathrm{CO}_{3}(2.76 \mathrm{~g}, 20.33 \mathrm{mmol})$ at $\mathrm{RT}$ under inert atmosphere. The resulting reaction mixture was gradually heated up to $65^{\circ} \mathrm{C}$ and stirred for 16 h. After completion of the reaction (by TLC), diluted with ice-cold water $(50 \mathrm{~mL}$ ) and extracted with EtOAc $(3 \times 75 \mathrm{~mL})$. The combined organic extracts were washed with water $(75 \mathrm{~mL})$, brine (50 mL), dried over anhydrous $\mathrm{Na}_{2} \mathrm{SO}_{4}$ and concentrated under reduced pressure. The crude material was purified by silica gel column chromatography (SiO2, 60-120 mesh) (eluent: 20\% EtOAc/Hexane) to afford compound $5(2.2 \mathrm{~g}, 3.57 \mathrm{mmol}, 62 \%)$ as off white solid.

${ }^{1} \mathrm{H}$ NMR (5 $00 \mathrm{MHz}, \mathrm{CDCl}$ ): $\delta 4.75$ (bs, 1H), 3.30 (s, 2H), 2.66 (t, J=8.2 Hz, 2H), 2.60 (t, J = 8.2 $\mathrm{Hz}, 2 \mathrm{H}), 2.83(\mathrm{~s}, 3 \mathrm{H}), 2.00(\mathrm{~s}, 6 \mathrm{H}), 1.86-1.72(\mathrm{~m}, 3 \mathrm{H}), 1.59-1.20(\mathrm{~m}, 34 \mathrm{H}), 0.90-0.82(\mathrm{~m}, 12 \mathrm{H})$. MS (ESI): $m / z 616[\mathrm{M}+1]^{+}$

\section{Step 4: (2S)-2, 5, 7, 8-tetramethyl-2-(4, 8, 12-trimethyltridecyl) chroman-6-yl 4-} aminobutanoate hydrochloride 6 . To a stirred solution of compound $-5(2.1 \mathrm{~g}, 3.41 \mathrm{mmol})$ in dry 1,4-dioxane $(5 \mathrm{~mL})$ was added $4 \mathrm{~N} \mathrm{1,4-dioxane} \mathrm{solution} \mathrm{in} \mathrm{HCl}(1.5 \mathrm{~mL})$ at $0^{0} \mathrm{C}$ under inert atmosphere. The resulting reaction mixture was stirred at RT for $9 \mathrm{~h}$. After completion of the reaction (by TLC), The resulting mixture was concentrated under reduced pressure, to get the sticky syrup, after washing with Ether (HPLC) to get the fine brown solid as final compound 6 (1.3 g, 2.52 mmol, 74\%). ${ }^{1} \mathrm{H}$ NMR ( Varian,400 MHz, CDCl3): $\delta 8.10$ (bs, 3H), 2.89 (t, J= $7.2 \mathrm{~Hz}, 2 \mathrm{H}$ ), ), $2.79(\mathrm{t}, J=10 \mathrm{~Hz}, 2 \mathrm{H}), 2.57(\mathrm{t}, J=8.0 \mathrm{~Hz}, 2 \mathrm{H}), 2.01(\mathrm{~s}, 3 \mathrm{H}), 1.91-1.89(\mathrm{~m}, 9 \mathrm{H}), 1.75(\mathrm{q}, J=7.2$ 
$\mathrm{Hz}, 2 \mathrm{H}), 1.40-1.33(\mathrm{~m}, 3 \mathrm{H}), 1.29-1.02(\mathrm{~m}, 23 \mathrm{H}), 0.84-0.80(\mathrm{~m}, 12 \mathrm{H}) . \mathbf{M S}(\mathbf{E S I}): \mathrm{m} / \mathrm{z} 516[\mathrm{M}+1]^{+}$

HPLC: $91.68 \%$.

\section{C: Conjugation of Alkyl Tocopheryl Derivetives with Dipeptide Valine-Cittrulin to get AMP- 001, AMP-002 and AMP-003 respectively.}

The common intermediate for the preparation of the above three derivatives is Boc-Val-Cit-OH, which has been prepared by the coupling reaction between Boc-Val-NHS and L-citrulline in DME- THF-water in the presence of sodium bicarbonate at room temperature in $50 \%$ yield after trituration with isopropyl ether.

\section{Step 1: Synthesis of Boc-Val-Cit-OH:}

Boc-Val-NHS (10 g, $31.8 \mathrm{mmol})$ in $80 \mathrm{~mL}$ of DME was added to a solution of L-Citrulline (5.85 g, $33.4 \mathrm{mmol})$ in $20 \mathrm{~mL}$ of THF and $\mathrm{NaHCO} 3(2.8 \mathrm{~g}, 33.4 \mathrm{mmol})$ in $80 \mathrm{~mL}$ of water. The mixture

Scheme 4
was stirred at room temperature overnight. Aqueous $15 \%$ citric acid $(200 \mathrm{~mL})$ was added and the mixture was extracted with $10 \%$ isopropyl alcohol/ ethyl acetate $(2 \times 200 \mathrm{~mL})$. The organic extract was washed with water $(2 \mathrm{X}$ $200 \mathrm{~mL}$ ) and the solvent was evaporated under vacuum. The resulting solid was triturated with $200 \mathrm{~mL}$ of isopropyl ether to afford the desired product $(6.0 \mathrm{~g}, 50 \%$, Scheme 4$) .1 \mathrm{H} \mathrm{NMR}$ : $\left(\mathrm{CD}_{3} \mathrm{OD}\right) \delta 0.92(3 \mathrm{H}, \mathrm{d}, \mathrm{J}=6.7 \mathrm{~Hz}), 0.97(3 \mathrm{H}, \mathrm{d}, \mathrm{J}=6.7 \mathrm{~Hz}), 1.44(9 \mathrm{H}, \mathrm{s}), 1.51-206(5 \mathrm{H}, \mathrm{m}), 3.12$ $(2 \mathrm{H}, \mathrm{t}, \mathrm{J}=6.7 \mathrm{~Hz}), 3.90(1 \mathrm{H}, \mathrm{d}, \mathrm{J}=7.0 \mathrm{~Hz})$ and $4.37-4.41(1 \mathrm{H}, \mathrm{m})$. 


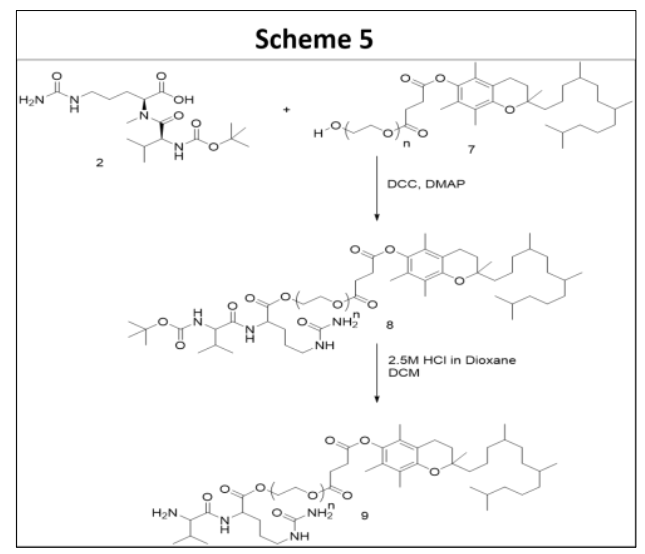

\section{Step: Synthesis of Val-Cit-TPGS (8)}

D-a-Tocopherol polyethylene glycol 1000 succinate (TPGS 7, 506 mg, 0.3 mmol), Boc-Val-Cit-OH 2 (374 mg, $1 \mathrm{mmol})$, DCC (208 mg, $1 \mathrm{mmol})$ and DMAP (61 mg, 0.5 $\mathrm{mmol})$ were dissolved in THF $(20 \mathrm{~mL})$ and stirred at room temperature for $16 \mathrm{~h}$. The precipitated solid (DCU) was removed by filtration and the filtrate evaporated on rotary evaporator. The residue was purified by silica-gel column chromatography using 10-20 \% methanol in dichloromethane as an eluent. Got desired product, 8 (155 mg) as off - white solid.

\section{Step III: Synthesis of AMP-001 (VC-TPGS 9).}

Compound 8 (150 mg) was dissolved in dry DCM $(10 \mathrm{~mL})$ and cooled to $0^{\circ} \mathrm{C}$. To the resulting solution was added $2.5 \mathrm{M} \mathrm{HCl}$ in dioxane $(3 \mathrm{~mL})$ and allowed to stir at room temperature for 12 h. Then it was concentrated and dried in vacuum oven to get desire product as light brown color solid (103 mg). ${ }^{1} \mathrm{HNMR}\left(\mathrm{CDCl}_{3}\right)$ is quite complex. ESI-MS 1942 (Scheme 5).

D: Synthesis of AMP-002: AMP-002 has been synthesized as follows. The reaction of Boc-Val-

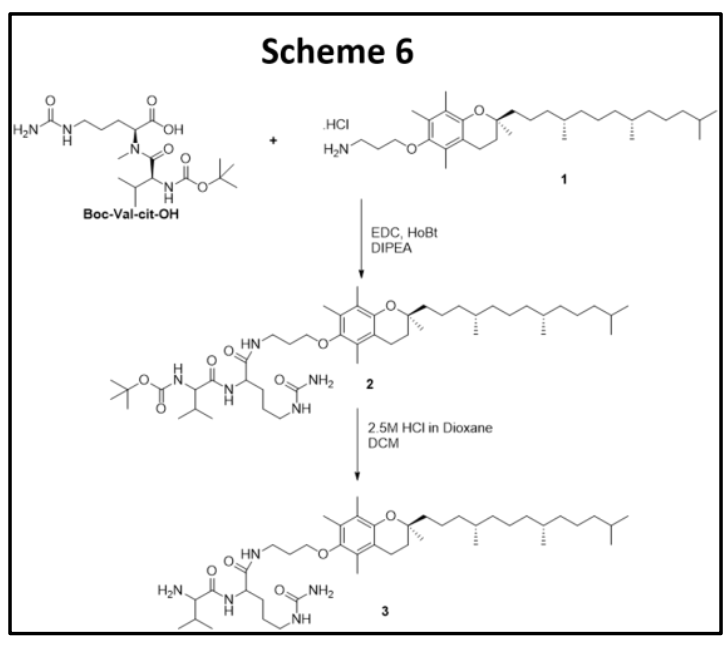
Cit-OH with TOPA in the presence of EDC and $\mathrm{HOBt}$ (1-hydroxybenzotriazole) in THF, gave Boc protected intermediate 2 . Boc group of $\mathbf{2}$ was removed by treating it with $2.5 \mathrm{M} \mathrm{HCl}$ in dioxane to afford the desired compound 3 .

\section{Synthesis of AMP-002 (VC-TOPA).}

$\mathrm{HCl}$ salt of TOPA (1, $330 \mathrm{mg}, 0.63 \mathrm{mmol})$, Boc-ValCit-OH (330 mg, $0.90 \mathrm{mmol})$, EDC (200 mg, $1 \mathrm{mmol}), \mathrm{HOBt}(100 \mathrm{mg}, 0.74 \mathrm{mmol})$ and N,Ndiisopropylethylamine $(0.3 \mathrm{~mL})$ were dissolved in THF $(10 \mathrm{~mL})$ under inert atmosphere. The 
resulting mixture was stirred at room temperature for $16 \mathrm{~h}$. It was quenched with brine $(5 \mathrm{~mL})$ and extracted with DCM $(2 \times 30 \mathrm{~mL})$. The organic layer separated, dried over $\mathrm{Na}_{2} \mathrm{SO}_{4}$, concentrated and purified by silica-gel column chromatography using 3-5 \% methanol in dichloromethane as an eluent. Got desired product, 2 (200 mg, 37\%) as brown color solid. ESIMS: $844.7(\mathrm{M}+\mathrm{H})$, Scheme 6.

\section{E: Synthesis of AMP-003: VC-TPEA}

\section{Step 1: Boc-VC-TPEA}

$\mathrm{HCl}$ salt of TPEA (4, $263 \mathrm{mg}, 0.475 \mathrm{mmol})$, Boc-Val-Cit-OH (263 mg, $0.70 \mathrm{mmol})$, EDC (193 mg, $1 \mathrm{mmol})$, HOBt (100 mg) and N,N-diisopropylethylamine $(0.3 \mathrm{~mL})$ were dissolved in THF $(20 \mathrm{~mL})$ and stirred at room temperature for $16 \mathrm{~h}$. To the resulting mixture was added brine (5 $\mathrm{mL}$ ) and extracted with DCM (2 X30 mL). The organic layer was dried over $\mathrm{Na}_{2} \mathrm{SO}_{4}$, filtered, concentrated and purified by silica-gel column chromatography using 3-5 \% methanol in dichloromethane as an eluent. Got desired product, 5 (180 mg, 43\%) as brown color solid. ESIMS; $872.6(\mathrm{M}+\mathrm{H})$.

\section{AMP-003: VC-TPEA}

Compound 5 (180 mg, $0.20 \mathrm{mmol})$ was dissolved in dry DCM $(10 \mathrm{~mL})$ and cooled to $0^{\circ} \mathrm{C}$. To the resulting solution was added $2.5 \mathrm{M} \mathrm{HCl}$ in dioxane $(3 \mathrm{~mL})$ and allowed to stir at room temperature for $12 \mathrm{~h}$. It was concentrated and dried in vacuum oven to get desire product as light brown color hydrochloride salt (150 mg, 94\%). \%). ${ }^{1} \mathrm{HNMR}\left(\mathrm{CDCl}_{3}\right): \delta$ 0.96-0.98 (m, 16H), 1.15-1.22 (m, 32H), 1.24-1.44 (m, 4H), 1.51-1.53 (m, 4H), 1.94-2.07 (m, 15H), $2.55(\mathrm{~m}, 5 \mathrm{H})$, ESI-MS; $772.6(\mathrm{M}+\mathrm{H})$.

\section{F: Synthesis of Doxorubicin-Tocopherol Conjugate}

\section{(i) Synthesis of Succinic Acid -Mono-Boc Hydrazine}


The structure of the final conjugated is shown in Scheme 2. Succinic anhydride (1 eq.) and DMAP

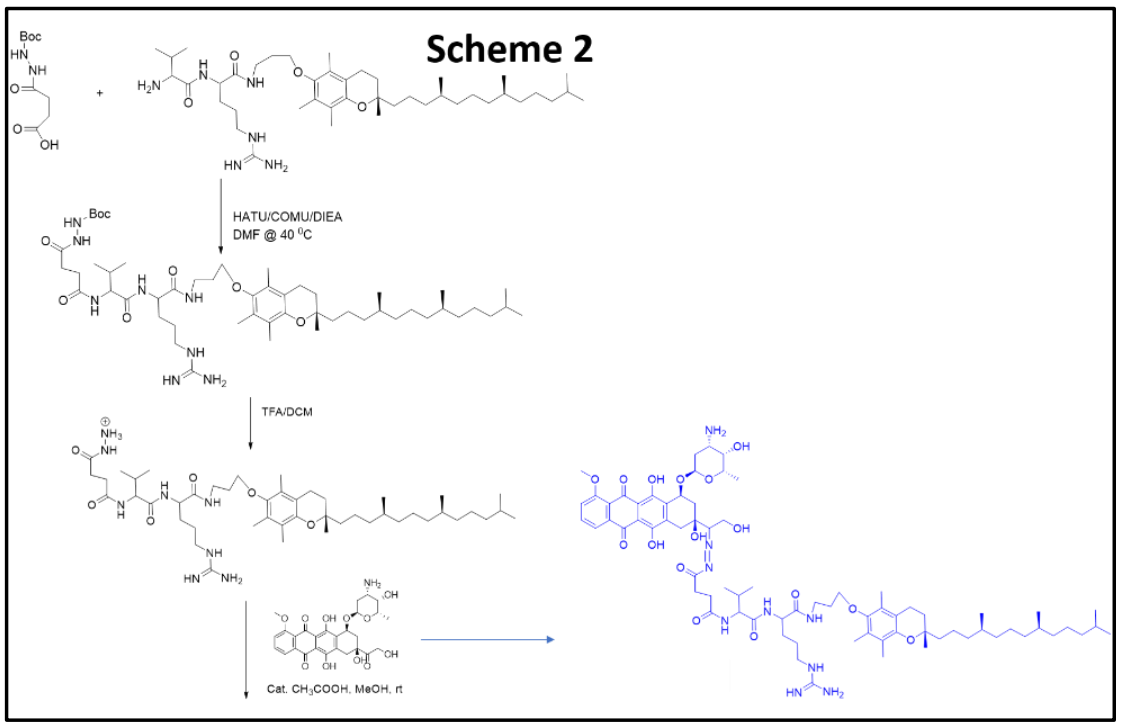
(0.08 eq.) were dissolved in dichloromethane $(40 \mathrm{~mL})$. After that, tert-butyl carbamate (1.3 eq.) was added at rt dropwise over 30 $\min$ to the reaction mixture under vigorous stirring. After addition was complete, the reaction mixture was stirred overnight at rt. Then, the reaction mixture was concentrated and re-dissolved in ethyl acetate (30 $\mathrm{mL})$. The ethyl acetate layer was washed $(20 \mathrm{~mL}$ X 3) with dilute $\mathrm{HCl}$ solution $(\mathrm{pH} \sim 5-6)$ followed by brine solution (20 mL X 3). Next, ethyl acetate layer was separated and dried over anhydrous $\mathrm{MgSO}_{4}$ and concentrated under reduced pressure. The colorless oily product was used in the next step without further purification.

\section{(ii) Synthesis of Succinic Acid -Mono-Boc Hydrazine-VA-propyl-Tocopherol conjugate}

Succinic Acid -Mono Boc Hydrazine (1.3 eq.) was dissolved in DMF (1 mL) in a scintillation vial. Then, HATU (4 eq.), COMU (4 eq.), and DIEA (10 eq.) were added to the reaction mixture and stirred for 5 min. After that, H-VA-propyl-Tocopherol conjugate (1 eq.) in DMF (1 mL) was added to the reaction mixture dropwise at rt. After addition was complete, reaction mixture was stirred at $40{ }^{\circ} \mathrm{C}$ for $24 \mathrm{~h}$. Reaction mixture was then concentrated under reduced pressure. The crude product was triturated with $\mathrm{NaHCO}_{3}(2 \mathrm{~mL} \times 3)$ followed by ice cold dilute $\mathrm{HCl}$ solution $(2 \mathrm{~mL} \times 3$; $\mathrm{pH} \sim 5-6)$ and ice cold water $(2 \mathrm{~mL} \times 3)$. The crude product was dried under reduced pressure and was utilized in the next step without further purification. 


\section{Synthesis of Succinic Acid -Hydrazine-VA-propyl-Tocopherol conjugate}

Succinic Acid -Mono-Boc Hydrazine-VA-propyl-Tocopherol conjugate was dissolved in TFA/DCM (1:1, $2 \mathrm{~mL})$ and was stirred for $4 \mathrm{~h}$. The reaction mixture was concentrated under reduced pressure. The crude was dissolved in purified water $(5 \mathrm{~mL})$ was washed with ethyl acetate $(5 \mathrm{~mL})$ in a separatory funnel. Water layer was separated, frozen, and lyophilized to obtain the pure product.

\section{Synthesis of Doxorubicin-succinic Acid -Hydrazine-VA-propyl-Tocopherol conjugate}

Doxorubicin (1 eq.) and succinic acid -hydrazine-VA-propyl-tocopherol conjugate (1 eq.) and catalytic amount of acetic acid were dissolved in $\mathrm{MeOH}(2 \mathrm{~mL})$ and stirred at $\mathrm{rt}$ for overnight in the dark. Then, the reaction mixture was concentrated under reduced pressure. After that, the doxorubicin-succinic Acid -Hydrazine-VA-propyl-Tocopherol conjugate was precipitated in $\mathrm{MeCN} / \mathrm{MeOH}(5: 1)$ in the dark at $0{ }^{\circ} \mathrm{C}$ (the maximum recovery was obtained in the refrigerator at $4{ }^{\circ} \mathrm{C}$ overnight). The product was collected by centrifugation (4000 rpm) over $10 \mathrm{~min}$. The supernatant was decanted. The precipitate was washed (x 5) with ice cold solution of $\mathrm{MeCN} / \mathrm{MeOH}(10: 1)$ by centrifugation (finally the supernatant would become a clear solution). Finally, the conjugate was vacuum dried in the dark and analyzed by $M S[E S I(+V e)] ; m / z=468.13$ when $z=3$ (sodiated).

\section{Cell Culture}

MDA-MB-231 cells (ATCC HTB-26) were cultured in RPMI 1640 culture medium with Lglutamine (Thermo-Fisher Scientific, Waltham MA, Catalog \#11875-093), supplemented with $10 \%$ fetal bovine serum and $1 \%$ Penicillin/Streptomycin (P/S) solution. Cells were incubated in a humidified incubator with $5 \% \mathrm{CO}_{2}$. MCF10A (CRL-10317) cells were cultured in DMEM /F12 Ham's Mixture supplemented with 5\% Equine Serum (Thermofisher Catalog \# 16050130), EGF $20 \mathrm{ng} / \mathrm{ml}$ (Sigma), insulin 10 $\mathrm{gg} / \mathrm{ml}$ (Sigma), hydrocortisone $0.5 \mathrm{mg} / \mathrm{ml}$ (Sigma), cholera toxin 100 
ng/ml (Sigma), 100 units/ml penicillin and $100 \mu \mathrm{g} / \mathrm{ml}$ streptomycin.

\section{Cell Viability Assays}

The Cell-Titer-Glo Luminescent Cell viability assay is a method to determine the number of viable cells in culture based on quantitation of the ATP present, as an indicator of metabolically active cells. Cells were seeded at a density of 400 cells / well in 384-well white-walled CulturPlate-384 cell culture plates (Perkin-Elmer, Waltham MA, Catalog \#6007680), and exposed to test agent the following day. Cells were allowed to grow in the presence of test agent for 72 hours, at which point Cell-Titer-Glo (Promega Corp., Madison WI, Catalog \#G7571) reagent was added at a volume equal to the cell culture medium in the plate, according to manufacturer's instructions. Luminescence was read on an Envision 2104 multilabel reader (Perkin-Elmer, Waltham WI). Cell viability curves were done in quadruplicate for each concentration.

\section{Cell Culture on Brain Tumor}

All samples were obtained from GBM surgical procedures following informed consent from patients. All experimental procedures were performed in accordance the Health Research Ethics Board of Alberta, Cancer Committee. Brain tumour stem cells (BTSCs) were cultured in neurosphere conditions on non-adherent plates in serum free media supplemented with EGF (20 $\mathrm{ng} / \mathrm{mL}$; Peprotech), FGF2 (20 ng/mL; R\&D Systems Inc) and heparin sulfate $(2 \mu \mathrm{g} / \mathrm{mL} ; \mathrm{R} \& D$ Systems). BTSC lines were confirmed to match their parental primary GBM tumor tissue by short tandem repeat profiling (Calgary Laboratory Services and Department of Pathology and Laboratory Medicine, University of Calgary). Authentication and testing of all cell lines was performed as per American Association for Cancer Research recommendations.

\section{Viability assays}


For viability assays BTSCs (Bt48, BT67, BT89, BT189) were cultured as neurospheres. To measure the drug effect, dissociated cells were plated in 96-well plates and cells were left untreated, treated with dimethyl sulfoxide (DMSO), AMP100, AMP002, AMP001 or AMP001A in $1 / 2 \log$ dose curves ranging from 0.003 to $10 \mu \mathrm{M}$ re-suspended in DMSO. Following 48 hours or 10-14 days of treatment, cell viability was measured. All cell viability measurements were performed using the alamarBlue ${ }^{\mathrm{TM}}$ reagent (Thermofisher) according to the manufacturer's protocol. All experiments were performed at 3 technical replicates/dose.

\section{Invasion Assays}

Invasion assays were performed as previously described (Restall et al, J Vis Exp. 2018 Aug 29;(138)). In brief, Small BTSC spheres were collected form culture flasks and treated in 6 -well plates. Spheres were treated with DMSO, $0.5 \mu \mathrm{M}$ AMP001 or $0.25 \mu \mathrm{M}$ Stattic for 24 hours. Spheres were then transferred to $1.5 \mathrm{~mL}$ Eppendorf tubes to allow gravity pellets to form. Media was removed and spheres were resuspended in a Rat Collagen I (Cultrex) matrix. $100 \mu \mathrm{L} /$ well of collagen suspended spheres was then transferred to a cold 96 -well plate with 3 experimental replicates for each treatment condition. Plates were transferred to an Incucyte Live Imaging System (Essen Bioscience). Area of cellular invasion was recorded hourly for 24 hours.

\section{Rats Breeding}

Breeding pairs were set with one homozygous male (rnu/rnu) and two homozygous females in a cage. Pregnant dams were separated right before new pups were born. Pups are weaned from mothers at 4 weeks of age. Since some breeding nude rats don't make milk sufficiently on the first pregnancy, pups of first litters rarely survive. Experienced moms produce pups the next pregnancy. For each litter produced after the first litter, 5-8 pups survive to weaning and females usually make up $50 \%$ of litter. 


\section{Cell implantation and tumor measurement}

The human breast cancer cell line MDA-MB-231 (ATCC) were grown in DMEM medium, supplemented with $10 \%(\mathrm{v} / \mathrm{v})$ FBS, penicillin $(10 \mathrm{U} / \mathrm{mL})$-streptomycin $(10 \mathrm{U} / \mathrm{mL})$ at $37{ }^{\circ} \mathrm{C}$ in humidified 5\% CO2 atmosphere. On the day of the cell implantation, MDA-MB 231 cells were trypsinized, washed with PBS and counted per $\mu$ L. Cells were placed in a sterile microcentrifuge tubes and keep them on ice. Cells were mixed 1:1 with Matrigel (right before the injection) and 12 million cells were injected in the next to last inguinal mammary fat pad in a volume of $100 \mathrm{uL}$. Tumor development was followed (length, width, and height, approximately 1 week after the implantation), Tumor volumes were calculated by the following formula: $(1 / 2 \times L \times W \times H)$, in which $\mathrm{L}$ is the length, $\mathrm{W}$ is the width, and $\mathrm{H}$ is the height. All rats were housed under a 12-hour lightdark cycle with free access to food and water. This study was performed in accordance with the "Guide for the Care and Use of Laboratory Animals" (2011) of the NIH. The protocol was approved by the Animal Care and Use Committee of the Johns Hopkins Medical Institutions (Baltimore, MD; Animal Welfare Assurance \# A-3273-01).

\section{DOX and AMP treatment Plan}

Rat with comparable sized tumors were randomly divided between the four treatment groups: DOX 5mg/kg, DOX 2.5 mg/kg and AMP-001 75/mg/kg combined, AMP-001 75/mg/kg alone, and no treatment. Doxorubicin was administered via jugular vein injection every 2 weeks for a total of 3 injections. AMP treatment was given intraperitoneally 24 hours before doxorubicin was given.

\section{Echocardiography}

Transthoracic echocardiography was performed on conscious rat using Vevo 2100 ultrasound scanner equipped with the 250 rat transducer. The rat was introduced into a DecapiCones disposable plastic restraint, plastic on top on the chest removed and pre-warm echo transmission gel was applied to the chest for the imaging. The heart was imaged in a two-dimensional mode 
followed by M-mode using the parasternal short axis view at a sweep speed of $200 \mathrm{~mm} / \mathrm{sec}$. After imaging, the ultrasound gel was wiped off and each rat thoroughly dried with disposable towels prior to home cage return. Measurements were acquired using the leading-edge method, according to the American Echocardiography Society guidelines. Left ventricle wall thickness and left ventricle chamber dimensions were acquired during the end diastolic and end systolic phase, including interventricular septum (IVSD), left ventricular posterior wall thickness (PWTED), left ventricular end diastolic dimension (LVEDD), and left ventricular end systolic dimension (LVESD). Three to five values for each measurement were acquired and averaged for evaluation. The LVEDD and LVESD were used to derive fractional shortening (FS) to measure left ventricular performance by the following equation: FS (\%) 1/4 [(LVEDD - LVESD)/LVEDD] x 100.

\section{SPECT imaging/Annexin V Labeling}

Recombinant human HYNIC annexin V prepared in Escherichia coli was obtained from the National Cancer Institute preclinical reagent program.11 To radiolabel the HYNIChydrazinonicotinamide-annexin $\mathrm{V}$ conjugate with $99 \mathrm{mTc}, 0.3 \mathrm{~mL}$ of saline containing approximately $1,000 \mathrm{MBq}$ of $99 \mathrm{mTc}$ pertechnetate was added. Subsequently, $0.2 \mathrm{~mL}$ of freshly prepared stannous-tricine was added to the solution. The reaction vial was incubated for 15 to 20 minutes at room temperature. Radiochemical purity was determined chromatographically with instant thin-layer chromatography paper (Gelman Sciences, Ann Arbor, MI) using an acid citrate dextrose buffer (Sigma-Aldrich, St Louis, MO) as the mobile phase. Labeling efficiency consistently exceeded $92 \%$, providing a specific radioactivity of $7.4 \mathrm{MBq} / \mu \mathrm{g}$ of protein.

In vivo SPECT was performed to quantify cell death in the heart. Rats were injected with 7 to $8 \mathrm{mCi} 99 \mathrm{mTc}-\mathrm{HYNIC}$-annexin $\mathrm{V}$ and imaged using a FLEX XSPECT system (Gamma Medica-ldeas, Northridge, CA) 1 hour post injection. Two imaging methods were used: highresolution dual-head single-pinhole imaging with 90 views and 30 s/view (total scanning time 45 
minutes) or high detection efficiency five-pinhole imaging, with 90 views and $30 \mathrm{~s} / \mathrm{view}$. The data were reconstructed with an OS-EM-based three-dimensional pinhole reconstruction algorithm. CT acquisition (75 kVp, $0.24 \mathrm{~mA}, 512$ projections, 0.1 s/projection) was also performed sequentially after SPECT imaging, and data were then registered with the corresponding SPECT images for anatomic delineation. (Reference: Gabrielson 2008 Molecular Imaging)

\section{Results and Discussion}

A: Drug Design: Most chemotherapeutics, currently used for TNBC treatments are non-specific or not targeted to any tumor specific biomarker ${ }^{23}$. Despite high off-target toxicity of chemotherapy, it is still a major player in the treatment of cancer. Particularly, true for triple negative breast cancer (TNBC) patients for whom no targeted therapy is not approved so far despite some of them are in clinical trials. The conventional targeted drugs are designed with a specific receptor in mind which is overexpressed in cancer cells compared to normal cells. For example, Cathepsin B is a well- studied tumor specific biomarker in various cancers including, breast, prostate, lung, liver, kidney brain and $\mathrm{TNBC}^{10}$. The prodrug approach of biological benign activity in circulation while, releasing the drug near target sites is an important part of the targeted drug design. Hence, both targeting and cleavage of the biologically active moieties are essential for high efficacy and safety of drugs. The conventional $\alpha$-tocopheryl succinate ( $\alpha$-TOS) is a classic example of working very well in vitro and in certain immunocompromised in vivo tumor models while, failed in clinically relevant immunocompetent tumor models. For example, studies by Ireland et.al; ${ }^{28}$ showed that $\alpha$-TOS was not only ineffective at the published doses, but resulted in severe side effects (e.g. loss of $C D^{3+} T$ cells, organ fusing under peritoneum similar to standard toxin Terpenen-4-ol). Even high doses $(471,235$ and $117 \mathrm{mg} / \mathrm{Kg}$ ) did not achieve tumor regression in vivo (Fig $1 \mathrm{a}$ and $\mathrm{b}$ in ref 28). Although $\alpha$-TOS has not been well studied in cardiomyocytes, $\alpha$-TOS enhances cellular ROS levels in mitochondria which may help cancer cells to die while, it also induces cell death in 
cardiomyocytes similar to the mechanism for doxorubicin ${ }^{29} . \alpha$-TOS is also sparingly soluble in water making it a difficult formulation for clinical purposes.

The lack of clinical product until now, for $\alpha$-TOS, has provided impetus for us to redesign drugs to include a) targeting/cleavable linker to release the drug near tumor which is expected to reduce the off-target toxicity, b) pegylation to make it water soluble/bioavailable at higher doses and to keep it intact as a pro-drug in blood circulation for a longer time so that permeable angiogenic sprouts can uptake the $\mathrm{drug}^{30}$. Valine-Citrulline is a dipeptide linker which is known to be cleaved by Cathepsin B. Hence, AMP-001 is designed to conjugate valine citrulline through pegylated units . AMP-002 and AMP-003 were designed with ethereal and ester link respectively without pegylation.

B: Selectivity: Targeting is essential to avoid side effects of the drug which was successfully adopted by bringing tumor specific biomarker Cathepsin B to which AMP class of drugs bind and get cleaved at the citrulline bond (see arrow in Scheme 1). The selectivity of AMP compounds for cancer cells is due to the binding of AMPs to Cathepsin B (which is overexpressed in several cancers) which cleaves and releases a) pegylated $\alpha$-TOS, b) ethereal oxy tocopheryl succinate and c) $\alpha$-TOS. We re-designed $\alpha$-TOS as a new drug molecule, now targeted to cancer cells through a VC linker, and soluble due to addition of a poly ethylene glycol (PEG) moieties (5mg/10mL solubility). PEGylation offers significant and distinct pharmacological advantages over the unmodified $\alpha$-TOS, including improved drug solubility, reduced dosage frequency, reduced toxicity, an extended circulating life, increased drug stability, enhanced protection from proteolytic degradation, decreased immunogenicity and antigenicity, and minimal loss of biological activity ${ }^{47-49}$. Thus, structurally and functionally AMP-001/003 are not equivalent of $\alpha$ TOS and hence, are considered as novel drugs. Scheme 2 describes the selectivity of AMP drugs. 
B: Biological Activity: Extensive biological properties and potential mechanism of AMP derivatives have been recently published by Pandurangi et. $\mathrm{al}^{31}$. Preliminary studies were concentrated on TNBC cells and cancer stem cells (CSCs). In continuation with it, in this study, AMPs are studied in glioblastoma (GBM) brain tumor stem cells (BTSCs) and tumor cells derived from patients to expand the application of AAAPT technology to other cancers. Cancer stem cells (CSCs) are believed to represent approximately $1 \%$ of the tumor as a distinct population and cause relapse and metastasis for greater than $40 \%$ of breast cancer patients ${ }^{11}$. Although the name CSC is an operational definition, these cells typically express higher levels of genes associated with stemness and epithelial to mesenchymal transition (EMT), which are involved in chemoresistance ${ }^{17}$. Chemotherapy can induce cell death only in bulk cancer cells and not in either CSCs or in low-responsive resistant cells. Amongst many proposed mechanisms of chemoresistance and relapse of cancer, cancer stem cells (CSCs) and cancer resistant cells (CRCs) either innate or drug induced stemness are found to be major culprits for therapy failure ${ }^{1}$. CSCs induction of resistance ${ }^{33}$, metastasis ${ }^{34}$ is imminent and found to be responsible for the high recurrence and making tumor cells refractory to the treatments. Conventional high dose chemotherapy and radiation therapy may even induce stemness in non-stem cancer cells ${ }^{27}$. GBM BTSCs encompass heterogenous populations of multipotent, self-renewing, and tumorigenic cells, which have been proposed to be at the root of therapeutic resistance and recurrence. We have shown in our earlier studies that AMPs target CSCs through inhibiting NF-kB pathway ${ }^{31}$. For GBM we selected brain tumor stem cells BT48, BT67, BT89 and BT 189 which grow under as neutrospheres (spheroid cell clusters). It is hypothesized that BTSCs can invade distant tissues far away from the tumor mass in GBM. First, the IC-50 values for AMP-001/003 are in the range 0.2$12 \mu \mathrm{M}$ which are comparable and in fact lower than many standard chemotherapeutics (Fig 1, see Table 1 of ref). The potency of AMP-001/003 is important for a potential clinical translation. Fig 2 shows BTSCs invasion into $0.4 \mathrm{mg} / \mathrm{mL}$ type I collagen surrounding matrix. Invasion was measured 
by quantifying the surface area of the cells as they invade the matrix over $24 \mathrm{hrs}$ using image analysis. Untreated BTSCs in DMSO depicted uncontrolled invasion of BTSCs into the collagen matrix in $24 \mathrm{hrs}$ (Fig $1 \mathrm{~A} \& \mathrm{D})$ in contrast to AMP-001 treatment $(0.5 \mu \mathrm{M}$, Fig 1, C \& F) and standard drug Statt 3 inhibitor (positive control, $0.25 \mu \mathrm{M}$, Fig 2 B \& E) which inhibited the invasion of BTSCs. The kinetics of invasion inhibition is graphically represented in Fig 2 G. Time-lapse videos of BTSC invasions are described in supplementary materials. In summary, we demonstrated the potency of AMP-001 to inhibit invasiveness of BT-48 chemo- and radioresistant BTSCs with efficiency comparable to an established inhibitor of BT-48 invasiveness, Stattic (Stat3 inhibitor).

C) Synergy with Chemotherapy and Inhibitor Drugs: Chemotherapy is widely used for the treatment of most cancers ${ }^{20}$. However, low therapeutic index with a high dose related off-target toxicity limits their use in clinics. Since cancer is a group of diseases, recent studies have proposed targeting multiple targets requires a combined formulation with the other targeted drugs at adjuvant or neoadjuvant settings. Such an approach requires synergy between the two proposed combined formulation. In continuing with the synergistic potential of AAAPT, we further extended the studies to patient derived tumor cells which reflects the true heterogenous nature of tumors. Basal-like breast cancer is the most common subtype of TNBC prevalent, particularly in African Americans who had worst clinical outcomes in terms of relapse and survival. The characteristics of basal like breast cancer is the loss of PTEN (Phosphatase and Tensin homolog) in patient population which activates PI3K activation leading cancer cells to desensitize themselves to intervention. Alternate pathways to sensitize these cells to chemotherapy may benefit these subsets of breast cancer patients. Patient derived xenograft models of basal-like breast cancer cell lines (WU-BC3) were developed by Ma et.al ${ }^{35}$. which were treated with AMP-001 to see if the heterogeneity of cells has any effect on the synergistic potential of AMP-001. WU-BC3 cancer cells derived from patients was assessed for the loss of PTEN expression which is most common in many patients as described by Ma et.al ${ }^{31}$. Photomicrographs of WU-BC3 GFP-knockdown Human induced mice (Him3) triple 
negative breast cancer cells showed distinct morphology for most cancer cells when treated with low doses of AMP-001 alone or low doxorubicin $(2 \mu \mathrm{M}$, Fig $3 \mathrm{~A})$ which is another front-line treatment for TNBC. However, as the concentration of AMP-001 increases (12 and $25 \mu \mathrm{M})$ the combination of AMP-001 with Doxorubicin resulted in significant increase cancer cell death compared to individual drugs. Recent reports on the same WU-BC3 cells, PTEN knockdown led to a more dramatic reduction in cell proliferation and tumor growth inhibition in response to pan-AKT inhibitors both in vitro and in vivo. Similar results were obtained for WU-BC3 PTEN knockdown Human induced mice (Him3) triple negative breast cancer cells where photomicrographs showed synergistic cell death for the combination compared to individual drugs.

\section{D) Potency of AMP-001 in inducing tumor regression and enhancing the efficacy of} doxorubicin at lower doses with no cardiotoxicity. We reported earlier the tumor regression by AMP-001 in TNBC mouse model without toxicity to off-target organs (e.g., heart, liver, and kidney $)^{31}$. In order to extend the synergistic potential of AMP-001 from in vitro to in vivo, we developed rat TNBC model where we could monitor the toxicity of AMP-001 in non-target organs including heart which is mostly affected organ when treated with Doxorubicin clinically. Both noninvasive SPECT and Ultrasound imaging were used to assess the cardiotoxicity thorough cell death marker (SPECT) and ejection fraction respectively. The results revealed that Doxorubicin, $(21 \mathrm{mg} / \mathrm{Kg})$ despite regressed tumor volume, it reduced the ejection fraction significantly from normal $65 \%$ to $45 \%$ (Fig 4 A \& C). However, the combination of AMP-001 (150mg/Kg, i.p.) with $50 \%$ reduced maximum tolerated dose (MTD) of Doxorubicin (10.5 mg/Kg, i.p.) achieved

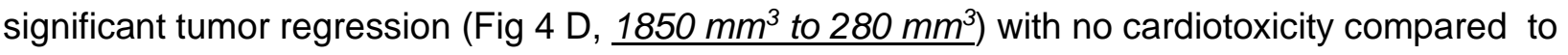
the MTD of Doxorubicin (i.e., $21 \mathrm{mg} / \mathrm{Kg}$, tumor regression, but cardiotoxic). Ultrasound imaging showed a ventricular dysfunction for Doxorubicin alone (EF < 45\%, Fig 4A) while AMP-001 with Doxorubicin combination retained ventricular function (EF $65 \%$, Fig 4, B-C). These data were corroborated with whole body SPECT imaging of cell death using 99mTc-Annexin which showed 
insignificant cell death in non-target organs for the combination (Fig 4, E1), while Doxorubicin alone showed significant cell death (Fig 4, E2).

The in vivo data were corroborated with data on pluripotent stem cell induced cardiomyocytes. Adult human induced pluripotent stem cell-derived (iPSC) cardiomyocyte technology offers the opportunity to accelerate the development of new therapeutic agents by providing a relevant human target for efficacy and safety that requires small amounts of test drug early in the research and development process. In other words, adult iPSC cardiomyocytes display normal cardiac physiology and electrophysiology, offering the potential to serve as a humanbased cell model for safety pharmacology and cardiotoxicity screening. All iPSC cardiomyocytes were no longer attached to the cell plate and numerous cell fragments were suspended in the cell media for $10 \mu \mathrm{M}$ doxorubicin while, AMP-001did not show the signs of toxicity even at $100 \mu \mathrm{M}$. After 24 hours exposure to AMP Conjugate all iPSCs were attached to the bottom of the cell well and contracting. These data demonstrate the IC50 for AMP -001 for cardiomyocytes may be greater than $100 \mu \mathrm{M}$. Photomicrograph of normal, beating induced pluripotent stem cell cardiomyocytes (iPSCs) in $0.8 \%$ DMSO is shown in Fig 5A which is similar to the photomicrograph for AMP-001 at $200 \mathrm{mM}$ (Fig 5B) conforming the low toxicity of AMP-001. In contrast, Doxorubicin showed morphological changes akin to apoptosis at $10 \mu \mathrm{M}$ (Fig 5C). The IC-50 of doxorubicin for iPSCs was found to be $9.6 \mu \mathrm{M}$ (Fig 5D). Concentration dependent viability assay for AMP-001 showed that iPSCs are viable even at $200 \mu \mathrm{M}$.

\section{Conclusions}

Targeting drugs to specific biological sites requires the identification of a tumor specific biomarker which may help monitoring the efficacy from preclinical to clinical phase. AAAPT technology incorporates both targeting and cleavable linker technologies using 
tumor specific biomarker Cathepsin B and dipeptide valine citrulline linker (VC) which is cleaved by Cathepsin B. Using such drug designs, variety of drugs were synthesized with tocopheryl as a scaffold. Particularly, one unique AMP-001 conjugated Doxorubicin (AMP-004) is unique with two cleavable linkers hydrazone and VC releasing two warheads (AMP-001 and Doxorubicin) in vivo. All the leading drugs showed synergy with Doxorubicin which is the standard care of treatment, particularly for triple negative breast cancer treatment. AMP-001 also synergized with patient derived TNBC cells which are more heterogenous compared to cultured TNBC cells. Our studies indicated a potential for AMP-001 to use it as a neoadjuvant to Doxorubicin to increase the therapeutic index of Doxorubicin. The synergistic potential of AMP-001 with Doxorubicin enabled to reduce the therapeutic dose by $50 \%$ which in turn reduced the cardiotoxicity associated with Doxorubicin. Further studies are required to extend the results to patient derived xenograft which mimics human tumor. 
bioRxiv preprint doi: https://doi.org/10.1101/2021.05.20.445072; this version posted May 21, 2021. The copyright holder for this preprint (which was not certified by peer review) is the author/funder. All rights reserved. No reuse allowed without permission. 


\section{Bibliography}

1. National Academies of Sciences, Engineering, and Medicine; Health and Medicine Division; Board on Health Care Services; National Cancer Policy Forum. The Drug Development Paradigm in Oncology: Proceedings of a Workshop. Washington (DC): National Academies Press (US); 2017 Jul 24. Proceedings of a Workshop. Available from: https://www.ncbi.nlm.nih.gov/books/NBK538013/

2. Nouri Z, Fakhri S, Nouri K, Wallace CE, Farzaei MH, Bishayee A. Targeting Multiple Signaling Pathways in Cancer: The Rutin Therapeutic Approach. Cancers (Basel). 2020;12(8):2276. Published 2020 Aug 14. doi:10.3390/cancers12082276.

3. For CD95/95L role see, a) Friesen C, Fulda S and Debatin KM; Deficient activation of the CD95 (APO- 1/Fas) system in drug-resistant cells. 1997, Leukemia 11: 1833-1841, b) Krammer PH, The tumor strikes back. New data on expression of the CD95 (APO1/Fas) receptor/ligand system may cause paradigm changes in our view on drug treatment and tumor immunology. 1997, Cell Death Differentiation 4: 362-364. For NFkB role, see c) Biswas DK, Shi Q, Baily S, Strickland I, Ghosh S, Pardee AB, Iglehart JD: NF-kB activation in human breast cancer specimens and its role in cell proliferation and apoptosis. Proc Natl Acad Sci U S A 2004, 101:10137-10142, d) Gilmore TD "Introduction to NF-KB: players, pathways, perspectives". Oncogene 25 (51): (2006). 6680-84. For PARP role, see e) Joseph I, Ferguson D, Palma J, Refici M, Godzicki L, Rodriguez L, et al. Poly(ADP-ribose) polymerase inhibitor, ABT-472 enhances antitumour activity of doxorubicin in human xenograft models and protects against druginduced cardiac toxicity. EJC. 2004 Suppl2\#8 Abs 473.

4. Das Gupta S, Suh N. Tocopherols in cancer: An update. Mol Nutr Food Res. 2016;60(6):1354-1363. doi:10.1002/mnfr.201500847. 
5. Prasad KN, Kumar B, Yan XD, Hanson AJ, Cole WC. Alpha-tocopheryl succinate, the most effective form of vitamin $\mathrm{E}$ for adjuvant cancer treatment: a review. J Am Coll Nutr. 2003 Apr;22(2):108-17. doi: 10.1080/07315724.2003.10719283. PMID: 12672706.

6. Ireland DJ, Kissick HT, Beilharz MW. Alpha-Tocopheryl succinate: toxicity and lack of anti-tumour activity in immuno-competent mice. Food Chem Toxicol. 2008;46: 508-12. doi:10.1016/j.fct.2007.08.030.

7. Water solubility

8. a) Abdullah LN, Chow EK-H. Mechanisms of chemoresistance in cancer stem cells. Clinical and Translational Medicine. 2013, 2:3. doi:10.1186/2001-1326-2-3, b) Reya T, Morrison S, Clarke M, Weissman I. Stem cells, cancer, and cancer stem cells. Nature. 2001;414(6859):105-111, c) Li X, Lewis M, Huang J, et al. Intrinsic resistance of tumorigenic breast cancer cells to chemotherapy. J Natl Cancer Inst. 2008;100(9):672679.

9. Lu J, Jiang F, Lu A, Zhang G. Linkers Having a Crucial Role in Antibody-Drug Conjugates. Int J Mol Sci. 2016;17(4):561. Published 2016 Apr 14. doi:10.3390/ijms17040561.

10. a) Kruszewski WJ, Rzepko R, Wojtacki J, Skokowski J, Kopacz A, Jaskiewicz K, et al. Overexpression of cathepsin B correlates with angiogenesis in colon adenocarcinoma. Neoplasma. 2004; 51: 38-43, b) Gondi, C.S., and Rao, J.S. (2013). Cathepsin B as a cancer target. Expert Opin. Ther. Targets 17, 281-291, c) Ebert MP, Kruger S, Fogeron ML, Lamer S, Chen J, Pross M, et al. Overexpression of cathepsin B in gastric cancer identified by proteome analysis. Proteomics. 2005; 5: 1693-704.

11. a) Carey LA, et al. The triple negative paradox: primary tumor chemosensitivity of breast cancer subtypes. Clin Cancer Res. 2007;13(8):2329-2334. (b) Dent R, et al. Triplenegative breast cancer: clinical features and patterns of recurrence. Clin Cancer Res. 
2007, 4429-4434, b) Hudis, C. A.; Gianni, L. (2011). "Triple-Negative Breast Cancer: An Unmet Medical Need". The Oncologist 16: 1-11.

12. a) Bauer KR, Brown M, Cress RD, Parise CA, Caggiano V. Descriptive analysis of estrogen receptor (ER)-negative, progesterone receptor (PR)-negative, and HER2negative invasive breast cancer, the so-called triple-negative phenotype. Cancer. 2007;109: 1721-1728. doi:10.1002/cncr.22618, b) Siddharth S, Sharma D. Racial Disparity and Triple-Negative Breast Cancer in African-American Women: A Multifaceted Affair between Obesity, Biology, and Socioeconomic Determinants. Cancers (Basel). 2018;10. doi:10.3390/cancers 10120514

13. Dent R, Trudeau M, Pritchard KI, Hanna WM, Kahn HK, Sawka CA, Lickley LA, Rawlinson E, Sun P, Narod SA. Triple-Negative Breast Cancer: Clinical Features and Patterns of Recurrence. Clin Cancer Res. 2007;13: 4429-4434. doi:10.1158/10780432.CCR-06-3045,

14. Stewart RL, Updike KL, Factor RE, Henry NL, Boucher KM, Bernard PS, Varley KE. A Multigene Assay Determines Risk of Recurrence in Patients with Triple-Negative Breast Cancer. Cancer Res. 2019;79: 3466-3478. doi:10.1158/0008-5472.CAN-18-3014

15. Jitariu AA, Cîmpean AM, Ribatti D, Raica M. Triple negative breast cancer: the kiss of death. Oncotarget. 2017;8(28):46652-46662. doi:10.18632/oncotarget.16938.

16. Al-Mahmood S, Sapiezynski J, Garbuzenko OB, Minko T. Metastatic and triple-negative breast cancer: challenges and treatment options. Drug Deliv Transl Res. 2018 Oct;8(5):1483-1507. doi: 10.1007/s13346-018-0551-3. PMID: 29978332; PMCID: PMC6133085.

17. de Ruijter TC, Veeck J, de Hoon JP, van Engeland M, Tjan-Heijnen VC. Characteristics of triple-negative breast cancer. J Cancer Res Clin Oncol. 2011;137(2):183-192. doi:10.1007/s00432-010-0957-x 
18. Marra, A., Trapani, D., Viale, G. et al. Practical classification of triple-negative breast cancer: intratumoral heterogeneity, mechanisms of drug resistance, and novel therapies. npj Breast Cancer 6, 54 (2020). https://doi.org/10.1038/s41523-020-00197-2.

19. Razzak AR, Lin NU, Winer EP. Heterogeneity of breast cancer and implications of adjuvant chemotherapy. Breast Cancer. 2008;15(1):31-4. doi: 10.1007/s12282-0070007-y. PMID: 18224391.

20. Liang Liu, Lin Yang, Wei Yan, Jing Zhai, Donald P. Pizzo, Peiguo Chu, Andrew, R. Chin, Meng Shen, Chuan Dong, Xianhui Ruan, Xiubao Ren, George Somlo and Shiz hen Emily Wang, Chemotherapy Induces Breast Cancer Stemness in Association with Dysregulated Monocytosis, Clin Cancer Res May 152018 (24) (10) 23702382; DOI: 10.1158/1078-0432.CCR-17-2545

21. Phi LTH, Sari IN, Yang YG, et al. Cancer Stem Cells (CSCs) in Drug Resistance and their Therapeutic Implications in Cancer Treatment. Stem Cells Int. 2018;2018:5416923. Published 2018 Feb 28. doi:10.1155/2018/5416923

22. Narui K, Ishikawa T, Shimizu D, Yamada A, Tanabe M, Sasaki T, Oba MS, Morita S, Nawata S, Kida K, Mogaki M, Doi T, Tsugawa K, Ogata H, Ota T, Kosaka Y, Sengoku N, Kuranami M, Niikura N, Saito Y, Suzuki Y, Suto A, Arioka H, Chishima T, Ichikawa Y, Endo I, Tokuda Y. Anthracycline could be essential for triple-negative breast cancer: A randomised phase II study by the Kanagawa Breast Oncology Group (KBOG) 1101. Breast. 2019 Oct;47:1-9. doi: 10.1016/j.breast.2019.06.003. Epub 2019 Jun 15. PMID: 31229857.

23. Yeh ETH, Tong AT, Lenihan DJ, Yusuf SW, Swafford J, Champion C, Durand J-B, Gibbs H, Zafarmand AA, Ewer MS. Cardiovascular complications of cancer therapy: diagnosis, pathogenesis, and management. Circulation. 2004;109: 3122-31. doi:10.1161/01.CIR.0000133187.74800.B9 
24. Papadimitriou M, Mountzios G, Papadimitriou CA. The role of PARP inhibition in triplenegative breast cancer: Unraveling the wide spectrum of synthetic lethality. Cancer Treat Rev. 2018 Jun;67:34-44. doi: 10.1016/j.ctrv.2018.04.010. Epub 2018 May 2. PMID: 29753961.

25. Poma P, Labbozzetta M, D'Alessandro N, Notarbartolo M. NF-kB Is a Potential Molecular Drug Target in Triple-Negative Breast Cancers. OMICS. 2017 Apr;21(4):225-231. doi: 10.1089/omi.2017.0020. PMID: 28388298.

26. Xu DP, Li Y, Meng X, et al. Natural Antioxidants in Foods and Medicinal Plants: Extraction, Assessment and Resources. Int J Mol Sci. 2017;18(1):96. Published 2017 Jan 5. doi:10.3390/ijms18010096

27. Wahba HA, El-Hadaad HA. Current approaches in treatment of triple-negative breast cancer. Cancer Biol Med. 2015;12(2):106-116. doi:10.7497/j.issn.2095-3941.2015.0030

28. Angulo-Molina A, Reyes-Leyva J, López-Malo A, Hernández J. The role of alpha tocopheryl succinate ( $\alpha-$ TOS) as a potential anticancer agent. Nutr Cancer. 2014;66: 167-76. doi:10.1080/01635581.2014.863367

29. Wang, X.F., Dong, L., Zhao, Y., Tomasetti, M., Wu, K., Neuzil, J., 2006. Vitamin E analogues as anticancer agents: lessons from studies with alpha-tocopheryl succinate. Mol. Nutr. Food Res. 50, 675-685.

30. Neuzil J, Zhao M, Ostermann G, et al. Alpha-tocopheryl succinate, an agent with in vivo anti-tumour activity, induces apoptosis by causing lysosomal instability. Biochem J. 2002;362(Pt 3):709-715. doi:10.1042/0264-6021:3620709

31. AAAPT Technology: Raghu Pandurangi, Compositions and methods for sensitizing lowresponsive tumors to cancer therapy, PCT Filed, Jan 2016, PCT/US16/68554, Publication number, WO/2017/131911, Publication date: 08/03/2017, International filing date:

12/23/2016, 
https://patentimages.storage.googleapis.com/6d/3a/2b/2e778b81566dbc/WO20171319 11A1.pdf, d)) Pandurangi RS, Tomasetti M, Verapazham ST, Paulmurugan R, Ma C, Rajput S, et al. (2021) A Priori Activation of Apoptosis Pathways of Tumor (AAAPT) technology: Development of targeted apoptosis initiators for cancer treatment. PLoS ONE 16(2): e0225869, https://doi.org/10.1371/journal.pone.0225869

32. Hu X, Ghisolfi L, Keates AC, Zhang J, Xiang S, Lee DK, Li CJ. Induction of cancer cell stemness by chemotherapy. Cell Cycle. 2012 Jul 15;11(14):2691-8. doi: 10.4161/cc.21021. Epub 2012 Jul 15. PMID: 22732500.

33. Citation: Lee HH, Bellat V, Law B (2017) Chemotherapy induces adaptive drug resistance and metastatic potentials via phenotypic CXCR4-expressing cell state transition in ovarian cancer. PLoS ONE 12(2): e0171044. https://doi.org/10.1371/journal.pone.0171044

34. Middleton JD, Stover DG, Hai T. Chemotherapy-Exacerbated Breast Cancer Metastasis: A Paradox Explainable by Dysregulated Adaptive-Response. Int $J$ Mol Sci. 2018;19(11):3333. Published 2018 Oct 26. doi:10.3390/ijms19113333.

35. Janetka JW, Piwnica-Worms H. Death by releasing the breaks: CHK1 inhibitors as cancer therapeutics. Trends Mol Med. 2011 Feb;17(2):88-96. PubMed PMID: 21087899. (b). Fracasso PM, Williams KJ, Chen RC, Picus J, Ma CX, Ellis MJ, Tan BR, Pluard TJ, Adkins DR, Naughton MJ, Rader JS, Arquette MA, Fleshman JW, Creekmore AN, Goodner SA, Wright LP, Guo Z, Ryan CE, Tao Y, Soares EM, Cai SR, Lin L, Dancey J, Rudek MA, McLeod HL, Piwnica-Worms H. A Phase 1 study of UCN-01 in combination with irinotecan in patients with resistant solid tumor malignancies. Cancer Chemother Pharmacol. 2011 Jun;67(6):1225-37. 
bioRxiv preprint doi: https://doi.org/10.1101/2021.05.20.445072; this version posted May 21, 2021. The copyright holder for this preprint (which was not certified by peer review) is the author/funder. All rights reserved. No reuse allowed without permission. 
bioRxiv preprint doi: https://doi.org/10.1101/2021.05.20.445072; this version posted May 21, 2021. The copyright holder for this preprint (which was not certified by peer review) is the author/funder. All rights reserved. No reuse allowed without permission.

Figures
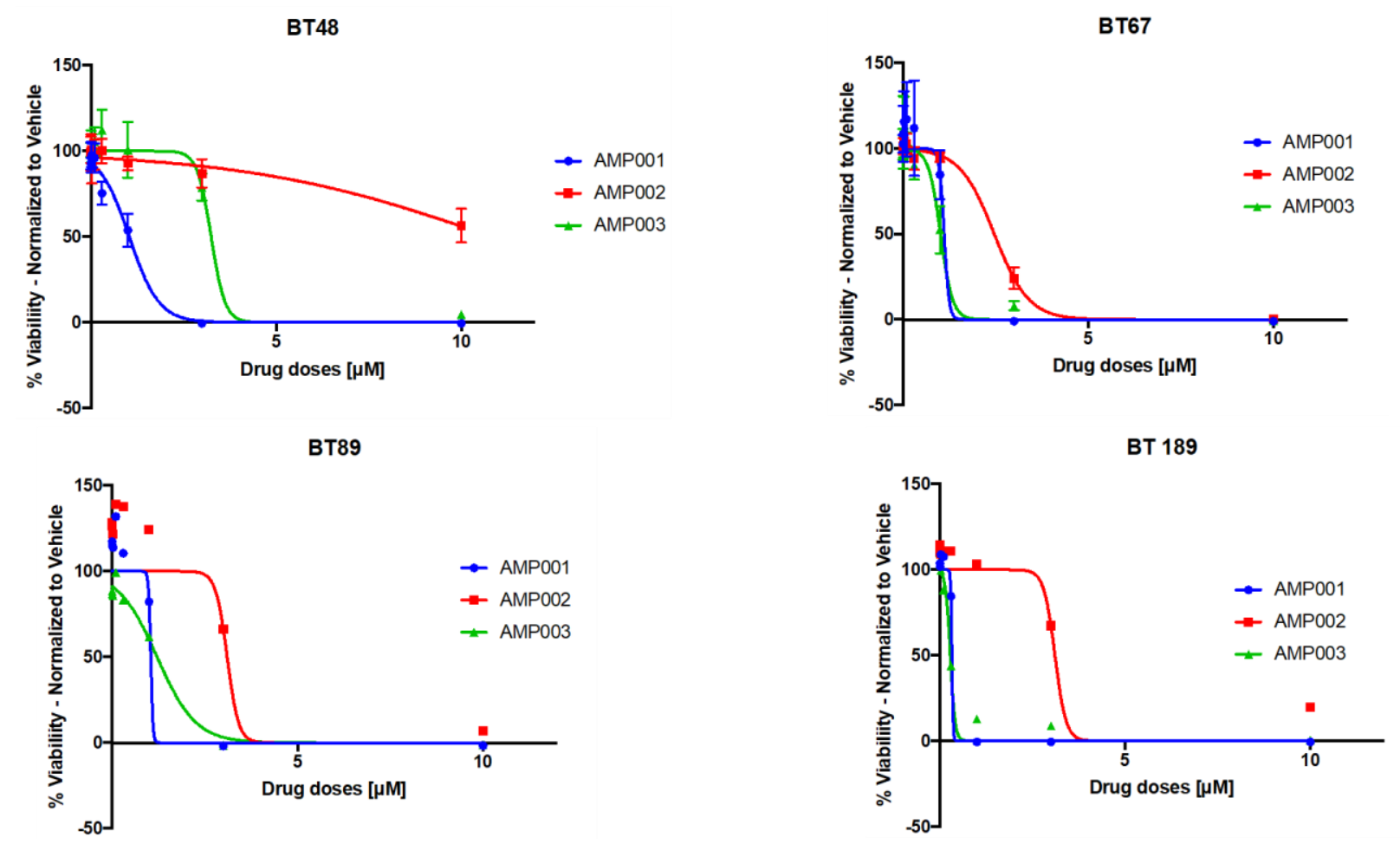

Fig 1: IC-50 values for AMP-001,002 \& 003 in brain tumor stem cells determined using CellTiter-Glo Luminescent Cell viability assay, $n=4, p<0.002$. 


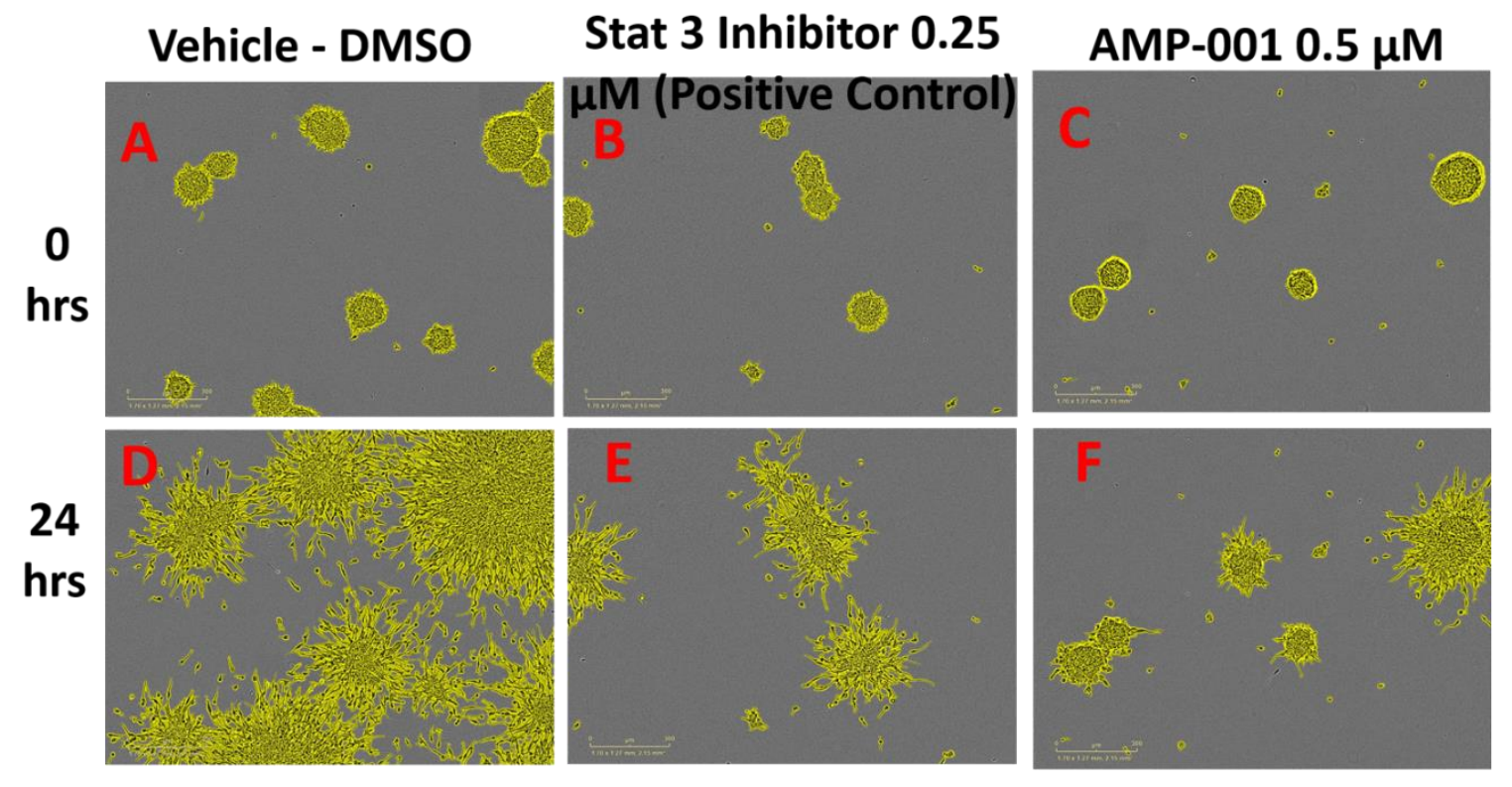

\section{Brain Tumor Stem Cell BT-48 Invasion}

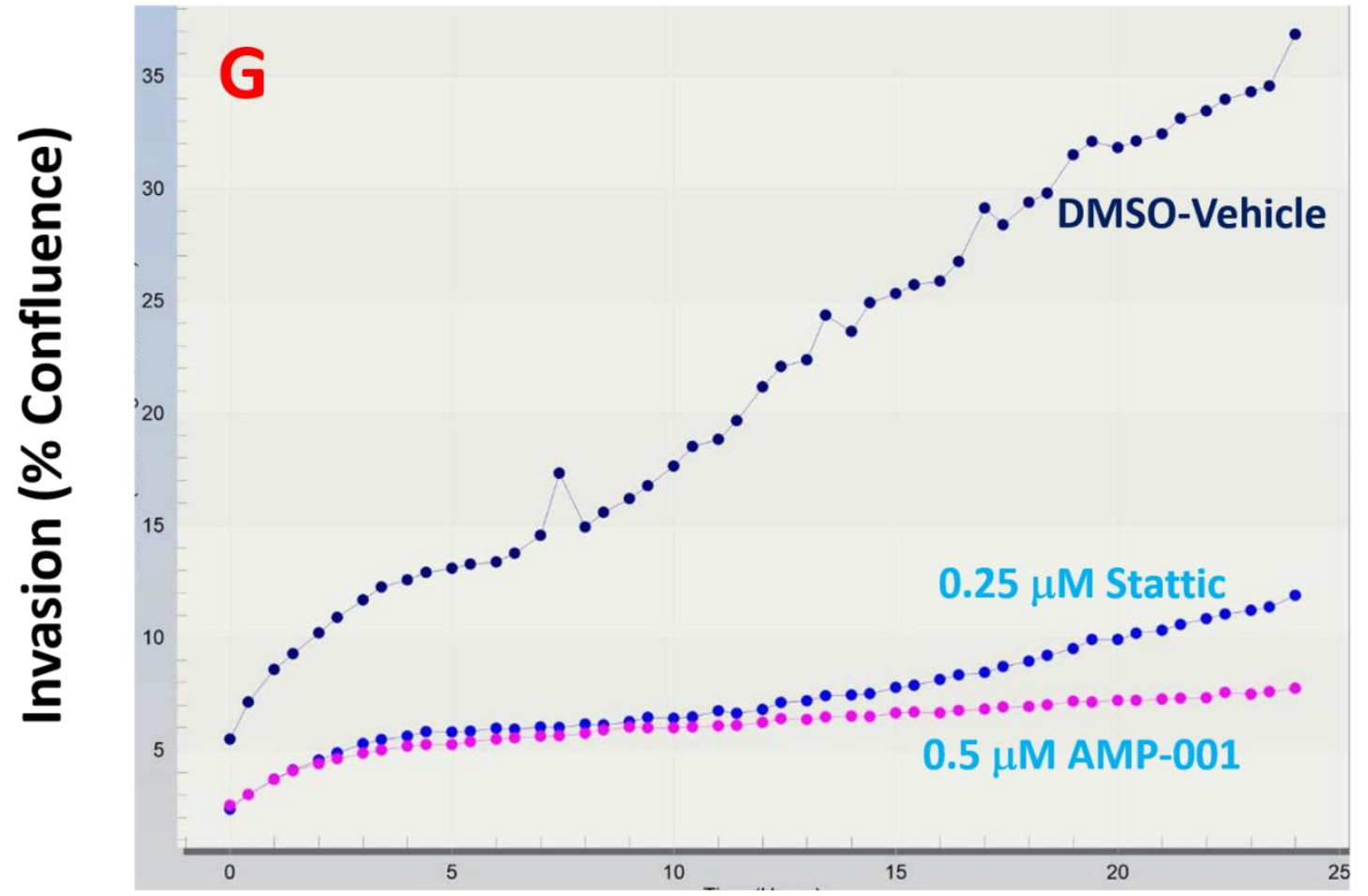

Fig 2: Live cell imaging of brain tumor stem cells (BTSC) neurosphere invasion into $0.4 \mathrm{mg} / \mathrm{mL}$ type I collagen matrix the surrounding matrix with A) Vehicle Control, B) Drug Stattic (positive control) and C) AMP-001 at 0 and D-E-F at 24 hrs. $n=3, P<0.003$, Error bars represent standard error of mean (SEM), Scale bar 300 mm, G: Graphical representation. 


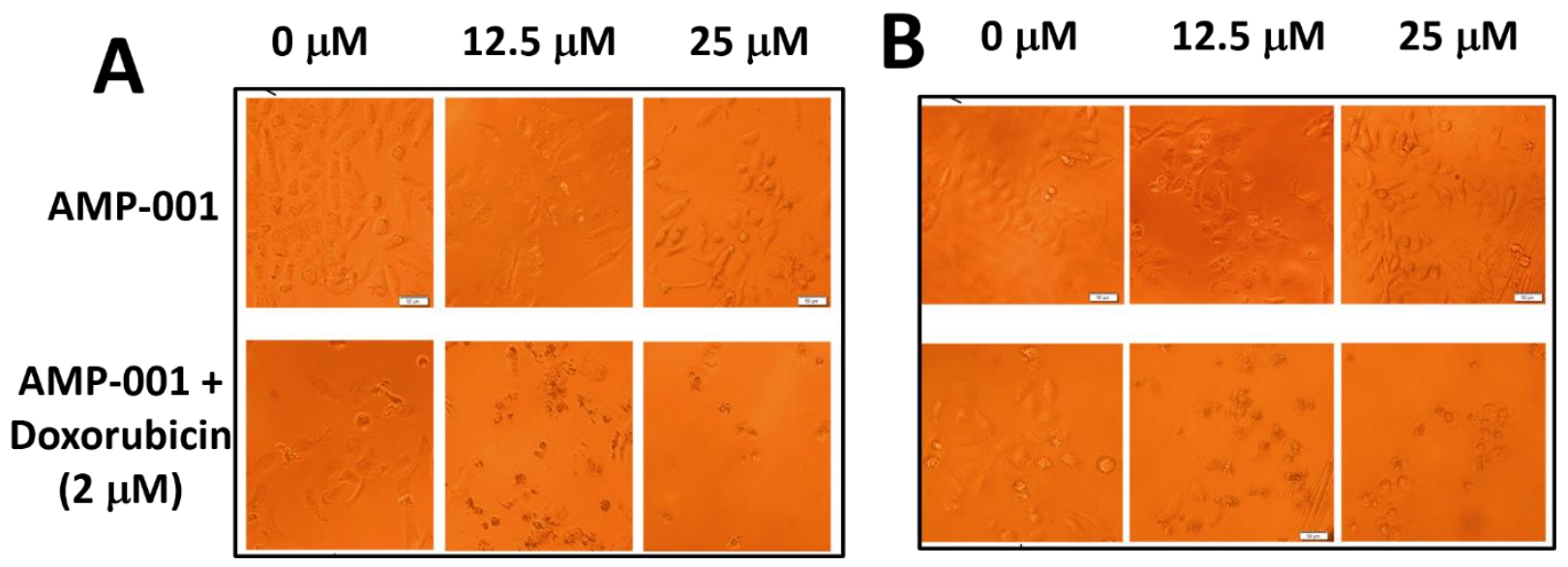

Fig 3: Synergistic induction by AMP-001 in knockdown Human

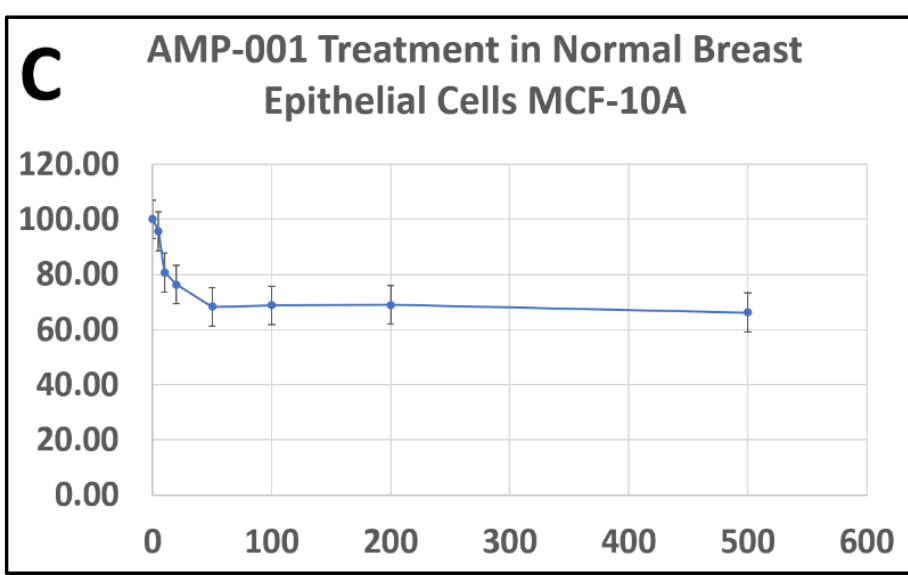

apoptosis A) GFPInduced

Mice (Him3) triple negative breast cancer cells (WU-BC3), B) PTEN knocked down Him3, C) IC-50 of AMP-001 in normal breast epithelial cells MCF-10A, $n=5, p<0.003$. 

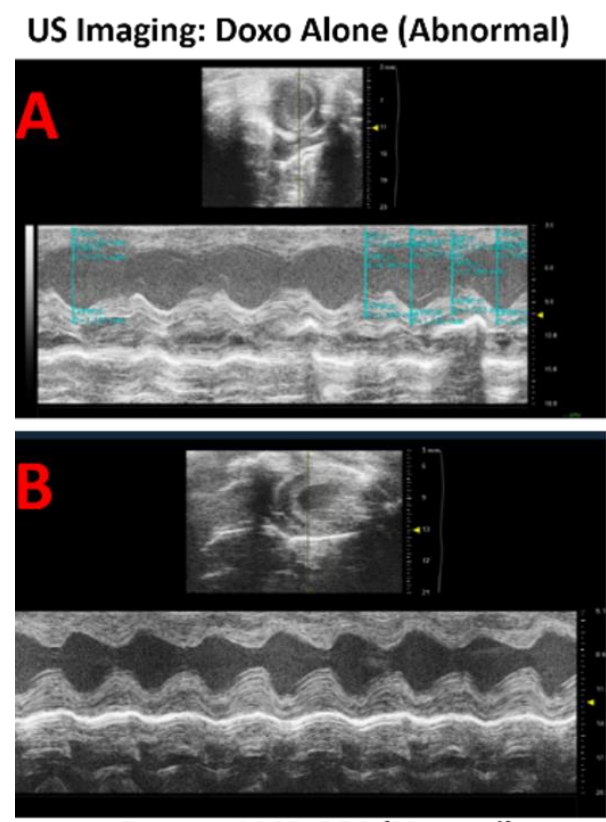

Doxo + AMP-001 (Normal)

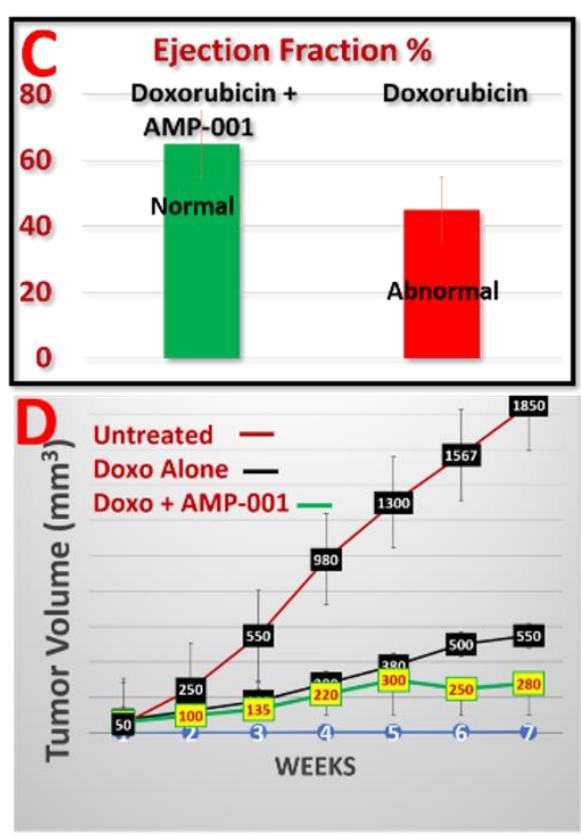

Coronal SPECT Imaging of Cell Death: Doxo Alone

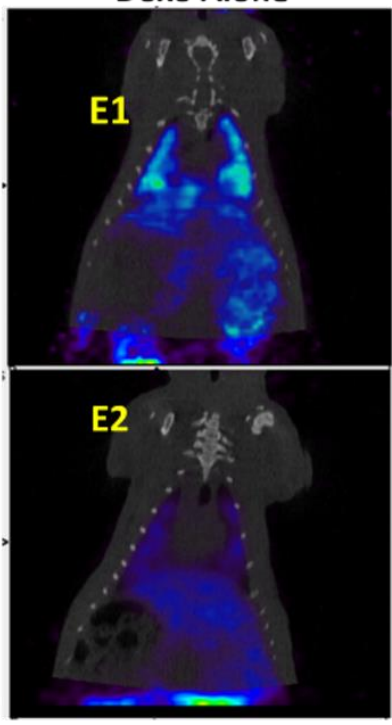

Doxo + AMP-001

Fig 4: Effect of combination of AMP-001 and Doxorubicin on the tumor regression and cardiotoxicity in triple negative breast cancer rat model; $A$ : Ultra sound imaging of the rat heart with a ventricular dysfunction, B: Reversal of ventricular dysfunction by the combination of AMP-001 and $50 \%$ of Doxorubicin therapeutic dose, C; Graphical representation of ejection fraction for the combination of AMP-001 and 50\% Doxorubicin (>65\%) compared to Doxorubicin alone, E: SPECT whole body imaging of cell death of TNBC rat using 99mTcAnnexin, E1: Doxorubicin alone Vs E2: Combination of AMP-001+ Doxorubicin. 

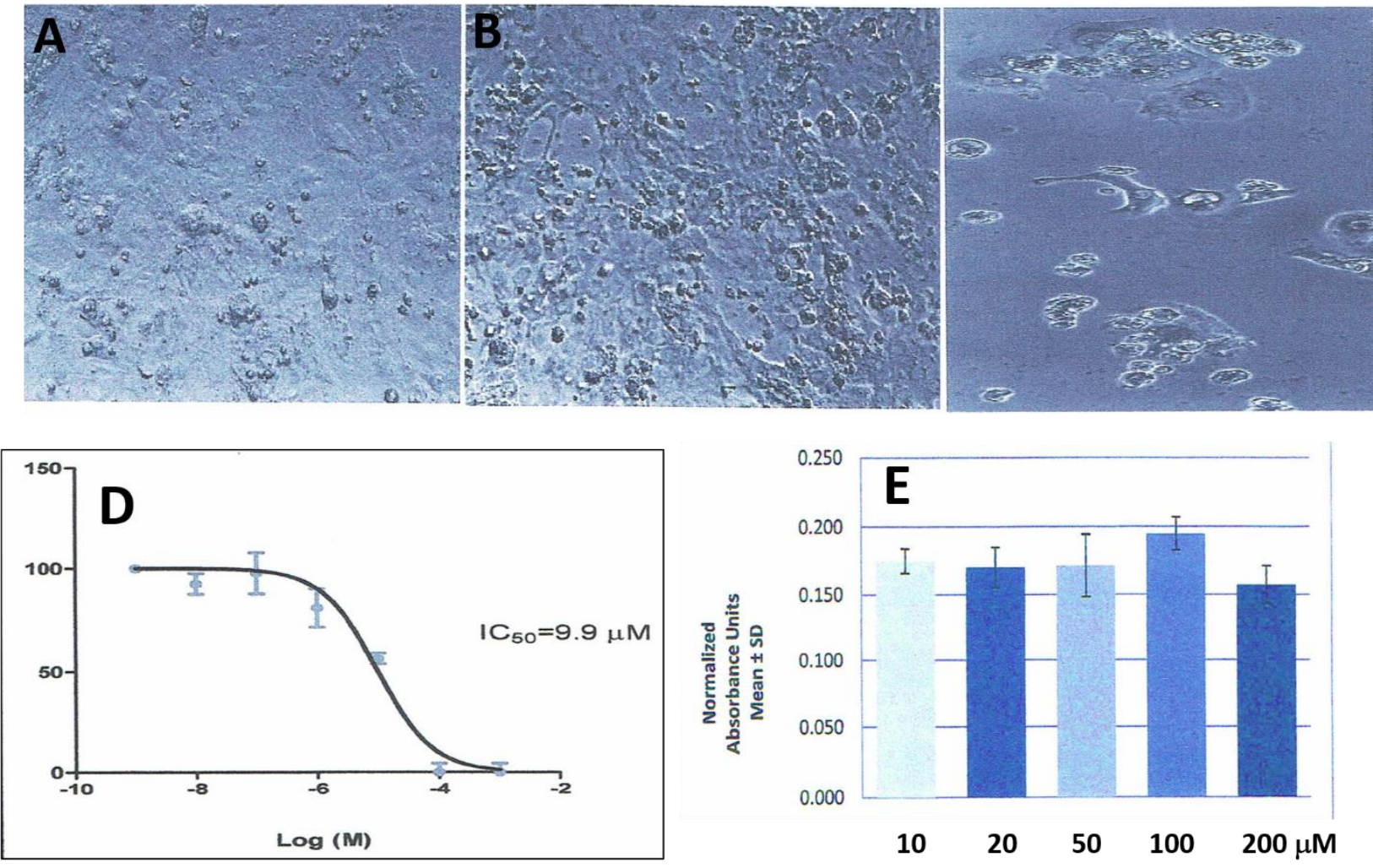

Fig 5: A: Photomicrograph of normal, beating induced pluripotent stem cell cardiomyocytes (iPSCs) in $0.8 \%$ DMSO, B: $200 \mu \mathrm{M}$ of AMP-001, C: $10 \mu \mathrm{M}$ Doxorubicin, D: IC-50 value for Doxorubicin in iPSCs, E: Concentration dependent viability for AMP-001 in iPSCs. 
bioRxiv preprint doi: https://doi.org/10.1101/2021.05.20.445072; this version posted May 21, 2021. The copyright holder for this preprint (which was not certified by peer review) is the author/funder. All rights reserved. No reuse allowed without permission. 